\title{
Hollow microcrystals of copper hexafluoroacetylacetonate-pyridine derivative adducts via supercritical $\mathrm{CO}_{2}$ recrystallization.
}

Ana López-Periago, ${ }^{\dagger, *}$ Oriol Vallcorba, ${ }^{\ddagger}$ Concepción Domingo ${ }^{\dagger}$ and José A. Ayllón ${ }^{\S, *}$

† Instituto de Ciencia de Materiales de Barcelona (CSIC), Campus UAB, 08193 Bellaterra, Spain.e-mail: amlopez@icmab.es

${ }^{\ddagger}$ ALBA Synchrotron Light Source, Cerdanyola del Vallés, Barcelona, Spain.

$\S$ Universidad Autónoma de Barcelona, Campus UAB, Bellaterra, Spain. e-mail: joseantonio.ayllon@uab.es

\begin{abstract}
An innovative crystallization process, based in the use of the eco-friendly supercritical carbon dioxide $\left(\mathrm{scCO}_{2}\right)$ solvent, is presented for the production of coordination compounds macrocrystals of general formula $\left[\mathrm{Cu}(\mathrm{hfacac})_{2}(\mathrm{dPy})_{2}\right]$, with intriguing prismatic hollow structures and single polymorphic forms. On the contrary, conventional solvents yielded compact microstructures. Studied pyridine derivatives (dPy) were 4-phenylpyridine, PhPy; 4benzylylpyridine, BzPy; and 4-acetylpyridine, AcPy. In the specific case of the [Cu(hfacac $\left.)_{2}(\mathrm{AcPy})_{2}\right]$ adduct, the use of $\mathrm{scCO}_{2}$ as a solvent allows obtaining a pure polymorph, while the conventional solvent trials yielded a mixture of two polymorphs. Four new crystalline structures have been resolved from single crystal X-ray diffraction. All the structures consist in mononuclear complexes connected through intermolecular interactions, including $\mathrm{H} \cdots \mathrm{H}, \mathrm{H} \cdots \mathrm{O}, \mathrm{F} \cdots \mathrm{F}, \mathrm{C}-\mathrm{F} \cdots \mathrm{C}_{\text {aromatic }}$ and/or $\mathrm{C}-\mathrm{F} \cdots \pi$ interactions, generating bidimensional networks that determine their crystallization mode in $\mathrm{scCO}_{2}$.
\end{abstract}




\section{Introduction}

The synthesis and design of metal-organic architectures, having diverse crystal topologies and functions, are of significant interest in crystal engineering and modern materials science and technology. ${ }^{1,2}$ The use of compressed or supercritical carbon dioxide $\left(\mathrm{scCO}_{2}\right)$ as a solvent in crystallization processes of organics and organometalic compounds has been deeply explored during the last 30 years. ${ }^{3,4}$ Small particles are typically generated by spray processes, in which the $\mathrm{scCO}_{2}$ can act either as a solvent, solute or antisolvent., ${ }^{5,6}$ Alternatively, the crystallization from a supercritical solution process, known as the CSS process, was developed to obtain large crystals. ${ }^{7}$ Only few references are available dealing with the use of the CSS process applied to crystallize small organic molecules ${ }^{8,9}$ and organometalics. ${ }^{10}$ Literature data on the solubility of different chemical compounds in $\mathrm{scCO}_{2}$ is being continuously augmented and summarized, which facilitates the design of new reactive processes ${ }^{11}$, as, for instance, the precipitation of multi-component molecular cocrystals. $^{12-14}$

In this work, the unique properties of the $\mathrm{scCO}_{2}$ solvent for the design of innovative processes in reactive crystal growth are explored. The main aim is to give a step towards the comprehension of the structural basis in the design of green crystallization methodologies for complex metal-organic products, other ways needing large amounts of organic solvents. The synthetic approach focused in the reactive synthesis of adducts in $\mathrm{scCO}_{2}$ that further crystallize as one-molecular products by solvent elimination. Particularly, adducts are synthetized by reacting copper hexafluoroacetylacetonate $\left[\mathrm{Cu}(\mathrm{hfacac})_{2}\right]$ and several monodentate pyridine derivatives (dPy) dissolved in $\mathrm{scCO}_{2}$.

Several uses are envisaged for both the designed supercritical process and the precipitated adduct crystals. The conventional operation unit of adducts crystallization is often used as a separation method. ${ }^{15}$ In supercritical extraction processes, the formation of $\mathrm{scCO}_{2}$ - 
soluble adducts is proposed for $\mathrm{CO}_{2}$ purification and recycling without significant pressure lost. The studied family of metal-complexes can be used for the removal of retained pyridine in $\mathrm{scCO}_{2}$ pyridine coal extracts. ${ }^{16}$ Although $\mathrm{scCO}_{2}$ has been applied successfully for the extraction of organic compounds in industry, direct extraction of metal ions using neat $\mathrm{scCO}_{2}$ has been found to be inefficient, owing to the weak solute-solvent interaction. A solution to this problem has been found by working with $\mathrm{scCO}_{2}$ containing $\beta$-diketones, already used to extract salts of heavy metals, uranium and rare earth elements from solutions or solid surfaces. ${ }^{17}$ The formation of pyridine adducts with the extract would facilitate the separation of the radioactive materials from the scCO2 solvent. In regard of the crystallized products, these complex structures can be imagined as new building blocks for supramolecular chemistry in $\mathrm{scCO}_{2}{ }^{18}$ The purpose of introducing metal ions into the adducts architecture may be structural or to attain desired functions such as catalytic, optical or magnetic. ${ }^{19}$ Finally, although the synthetized adducts do not currently have any reported clinical use, this work would help to lay the foundations for the sustainable crystallization of copper-based adducts that are widely used in medicinal inorganic chemistry, ${ }^{20}$ by taking advantage of the numerous positive properties described for supercritical production technology in the pharmaceutical industry. ${ }^{21}$ As a point of interest, hollow crystals were precipitated using the $\mathrm{scCO}_{2}$ approach, which also find applications in pharmacy, since these solids are generally more soluble and faster dissolving than their dense-crystals counterparts. ${ }^{22}$

The objective of this work was to verify the ability of the $\mathrm{sCCO}_{2}$ solvent to interact with chosen building blocks to effectively produce high quality crystals of different $\left[\mathrm{Cu}(\mathrm{hfacac})_{2}(\mathrm{dPy})_{2}\right]$ adducts. Crystallographic, morphological, physicochemical and textural data of CSS prepared samples were measured and compared against those of crystals obtained by a more conventional evaporation solvent method. Moreover, four new crystal structures were determined by monocrystal X-ray diffraction. 


\section{Materials and methods}

\subsection{Materials}

Copper hexafluoroacetylacetonate $\left[\mathrm{Cu}(\mathrm{hfacac})_{2}\right]$ was chosen as the metal complex, combined with either 4-phenylpyridine (PhPy), 4-benzylpyridine (BzPy) or 4-acetylpyridine (AcPy) as the organic building block, to form the adducts (Fig. 1). Dichloromethane (DCM), heptane, methanol and water were used as solvents in the conventional evaporation method. Reagents and liquid solvents were all purchased from Sigma Aldrich and used without further purification. Compressed $\mathrm{CO}_{2}(99.995 \%)$ was supplied by Carburos Metálicos S.A., Air Products Group (Spain).

\subsection{Methods}

\subsubsection{Supercritical procedure}

Sample preparation under $\mathrm{scCO}_{2}$ was carried out in a high pressure equipment described elsewhere. ${ }^{4}$ A stainless steel reactor of $100 \mathrm{~mL}$ volume, equipped with two opposite sapphire windows, was used for the crystallization experiments. The autoclave was charged with ca. 80-100 mg of [Cu(hfacac) $)_{2}$ and about 50-80 mg of a pyridine ligand, in a 1:2 Cu:dPy molar ratio. The reagents and a small magnetic stir bar were added to a $10 \mathrm{~mL}$ Pyrex vial capped with filter paper and placed within the reactor. The cell was then sealed and the specific protocol of pressurization/depressurization schematized in Fig. 2 was started, taking into account that crystal formation proceeded in five steps: reagents dissolution, reagents reaction, product precipitation, product dissolution and product recrystallization. First, at ambient temperature, the reactor was filled with liquid $\mathrm{CO}_{2}$ at 60 bar, while stirring at 500 rpm. The system was then heated up to $60{ }^{\circ} \mathrm{C}$ with a concomitant pressure increase of $15-20$ bar. A syringe pump was used to further increase the pressure to 200 bar. These working conditions of $200 \mathrm{bar}, 60{ }^{\circ} \mathrm{C}$ and $500 \mathrm{rpm}$ were maintained for a period of time of $40 \mathrm{~min}$ for 
samples involving AcPy and BzPy ligands and $180 \mathrm{~min}$ for crystals constituted by $\mathrm{Cu}(\mathrm{hfacac})_{2}$ and PhPy. After the dissolution of the initially formed precipitate, the stirrer was switched off, and the temperature and pressure were decreased in a slow controlled depressurization stage, performed using a fine-adjustment needle valve, giving place to crystals formation. To start, the temperature was decreased to $45{ }^{\circ} \mathrm{C}$ reaching the reactor a pressure of 160 bar. Decompression proceed then in two steps, attaining in the first one pressures close to the critical (80-75 bar) in ca. $2 \mathrm{~h}$, and further achieving ambient pressure in the second in ca. $5 \mathrm{~h}$. At the end of the second depressurization step, the temperature was also set to ambient temperature. The this way supercritically recrystallized (src) samples were labeled as $\operatorname{src}\left[\mathrm{Cu}(\mathrm{hfacac})_{2}(\mathrm{dPy})_{2}\right]$. In selected experiments, crystals were collected from the reactor at different stages in the pressurization profile. First, reagents were allowed to react under liquid $\mathrm{CO}_{2}$ at the low pressure of 60 bar at $25{ }^{\circ} \mathrm{C}$. After $10 \mathrm{~min}$ the formation of a precipitate was observed and the system was rapidly depressurized in ca. 20 min. Recovered sample was labeled as $\operatorname{lp}\left[\mathrm{Cu}(\mathrm{hfacac})_{2}(\mathrm{dPy})_{2}\right]$. Second, a similar reaction was maintained for $30 \mathrm{~min}$ in $\mathrm{scCO}_{2}$ at 200 bar and $60{ }^{\circ} \mathrm{C}$, and the system was quickly depressurized just after reaching supercritical precipitation. Recovered sample was labeled as sp[Cu(hfacac $\left.)_{2}(\mathrm{dPy})_{2}\right]$.

\subsubsection{Conventional method}

[Cu(hfacac) $)_{2}$ (0.209 mmol) dissolved in DCM (15 mL) and two equivalents of the chosen pyridine derivative (dPy) ligand (0.418 mmol), also dissolved in DCM (15 mL), were mixed yielding green solutions. Heptane $(15 \mathrm{~mL})$ was then added as an antisolvent and the solutions obtained were allowed to evaporate in open vessels under ambient conditions. Formed crystals were then filtered off, washed with hexane and let to dry at room temperature. Additionally, for AcPy a similar route was applied, but using methanol as a 
solvent and adding water as the antisolvent. The samples obtained using conventional solvents were labeled as conv[Cu(hfacac $\left.)_{2}(\mathrm{dPy})_{2}\right]$.

\subsection{Characterization}

The weight percentage of $\mathrm{C}, \mathrm{H}$ and $\mathrm{N}$ in the obtained samples was measured by elemental analysis using a Flash EA2000 Thermo Fisher Scientific analyzer (Table 1). ATRIR spectra were recorded using a Perkin Elmer Spectrum One spectrometer equipped with a Universal ATR sampling accessory. Spectra were collected with $2 \mathrm{~cm}^{-1}$ spectral resolution in the $2000-650 \mathrm{~cm}^{-1}$ range. The textural properties were determined by $\mathrm{N}_{2}$ adsorption at -196 ${ }^{\circ} \mathrm{C}$ applying the BET method, using an ASAP 2000 Micromeritics INC. Samples were first degassed at $60{ }^{\circ} \mathrm{C}$ for $24 \mathrm{~h}$. Morphological features were examined by optical and scanning electron microscopy (SEM) with a Zeiss Merlin FE-SEM apparatus, and a QUANTA FEI 200 FEG-ESEM microscope.

The conv $\left[\mathrm{Cu}(\mathrm{hfacac})_{2}(\mathrm{dPy})_{2}\right]$ and $\operatorname{src}\left[\mathrm{Cu}(\mathrm{hfacac})_{2}(\mathrm{dPy})_{2}\right]$ products were obtained as green macrometric crystals, and, thus, single crystal X-ray diffraction data could be collected using a SMART APEX (Bruker) with a CCD detector. Measurements were performed at $23 \pm$ $1{ }^{\circ} \mathrm{C}$. Data were collected with a graphite monochromatized Mo K $\alpha$ radiation $(\lambda=0.71073 \AA)$, using an $\omega / 2 \theta$ scan technique. The structures were solved by the direct method program $\mathrm{XLENS}^{23}$ and refined by the full matrix least-squares method on $\mathrm{F}^{2}$ for all unique measured data using SHELXL (ver. 2014/7). ${ }^{24}$ Unit cell parameters were determined from the automatic centering of $5839\left(4.46-52.87^{\circ}\right), 5830\left(4.56-50.15^{\circ}\right), 2514\left(4.33-47.14^{\circ}\right)$ and $3000(4.60-$ $\left.40.69^{\circ}\right)$ reflections $\left(2 \theta\right.$ range) for compounds $\left[\mathrm{Cu}(\mathrm{hfacac})_{2}(\mathrm{PhPy})_{2}\right],\left[\mathrm{Cu}(\mathrm{hfacac})_{2}(\mathrm{BzPy})_{2}\right], \alpha-$ $\left[\mathrm{Cu}(\mathrm{hfacac})_{2}(\mathrm{AcPy})_{2}\right]$, and $\beta-\left[\mathrm{Cu}(\mathrm{hfacac})_{2}(\mathrm{AcPy})_{2}\right]$ respectively, followed by a least-square refinement. Tables 2-5 provide crystallographic details and selected bond distances, angles, and intermolecular interactions. Crystallographic data for structures reported in this paper 
have been deposited in the Cambridge Crystallographic Data Center under reference numbers CCDC 1443468, 1443469, 1443470 and 1443471. These data can be obtained free of charge via www.ccdc.cam.ac.uk/data_request/cif.

For all the solved crystal structures, the rotation disorder of the $\mathrm{CF}_{3}$ groups (due to their high symmetry and low energy barrier of the rotation about the threefold symmetry axis) has been modeled by assigning (to each of the $\mathrm{CF}_{3}$ groups) six fluorine positions with elongated thermal ellipsoids. ${ }^{25}$ All six C-F distances have been restrained to be equal (elasticity $=0.02 \AA$ ), as well as all six F $\cdots$ F distances (elasticity $=0.04 \AA$ ) and also the F $\cdots \mathrm{X}$ distances (elasticity $=0.04 \AA$ ), being $\mathrm{X}$ the atom to which the $\mathrm{CF}_{3}$ group is bonded. Also, rigid bond restraints (elasticity $=0.01 \AA$ ) have been applied to the six F atoms and the $\mathrm{C}$ atom conforming each $\mathrm{CF}_{3}$ group. Considering all these conditions, a total of 63 restraints for each $\mathrm{CF}_{3}$ group are applied.

Synchrotron powder XRD was carried out on the high resolution powder diffraction endstation of the MSPD beamline (BL04) ${ }^{26}$ of ALBA synchrotron using the microstrip MYTHEN-II detector (6 modules, 1280 channels/module, $50 \mu \mathrm{m} /$ channel, sample-to-detector distance $550 \mathrm{~mm}$ ) at an energy of $20 \mathrm{keV}$ (wavelength $=0.61976 \AA$ ). All the samples were softly milled in an agate mortar, introduced into Ø0.7 mm glass capillaries and measured in transmission mode at room temperature.

\section{Results and discussion.}

The process of reactive crystallization for adducts formation involving dPy ligands was surveyed under $\mathrm{scCO}_{2}$ conditions by the CSS process. The CSS can be treated as an extension of the classical batch liquid solvent crystallization process, in which crystals are obtained either by gradual cooling down, or slow solvent evaporation, of a saturated solution. In the $\mathrm{scCO}_{2}$ batch CSS method, both the temperature and the pressure can be used to trigger 
crystal growth. The chemical structure of used reagents and obtained products are schematized in Fig. 1. Pyridine reagents were chosen because they have a significant solubility in $\mathrm{scCO}_{2}$. Indeed, under working experimental conditions, organic pyridine linkers could be dissolved in $\mathrm{scCO}_{2}$ at the used concentration. Moreover, pyridine and its derivatives are attractive monodentate nitrogen ligands with an exo $\mathrm{N}$-donor site available for reacting with metals. Although most solubility data in $\mathrm{scCO}_{2}$ refers to organic substances, it has been reported that $\mathrm{scCO}_{2}$ can also dissolve metal-containing coordination compounds. ${ }^{27}$ The [Cu(hfacac $\left.)_{2}\right]$ building block has a significantly high solubility in compressed and supercritical $\mathrm{CO}_{2}$, determined by the fluoride content $\left(\mathrm{y}=6.110^{-4}\right.$ at $40{ }^{\circ} \mathrm{C}$ and 100 bar). ${ }^{28}$ Reports on the use of $\mathrm{scCO}_{2}$ as a solvent for the synthesis of coordination compounds are very scarce. ${ }^{29}$ Previous studies have described the use of $\mathrm{scCO}_{2}$ to process $\left[\mathrm{Cu}(\mathrm{hfacac})_{2}\right]$, either to deposit copper films, ${ }^{30,301}$ to produce copper particles, ${ }^{32}$ to obtain one-dimensional coordination polymers, ${ }^{33}$ or for the etching of copper using hfacac in $\mathrm{scCO}_{2} \cdot{ }^{34,35}$ In the etching conditions, a $\left[\mathrm{Cu}(\mathrm{hfacac})_{2}(\mathrm{Py})_{2}\right]$ adduct was probably formed, although the authors did not report its isolation or characterization.

In this work, crystal formation proceeded in five steps following the pressurization/depressurization protocol schematized in Fig. 2: reagents dissolution, reaction, precipitation, product dissolution and recrystallization. Reagents dissolution, reaction between the two building blocks, and precipitation of the products occur almost instantly in the reactor during system pressurization with $\mathrm{CO}_{2}$. Indeed, the formation of a green precipitate was already observed under liquid $\mathrm{CO}_{2}$ conditions at 60 bar, which maintains the texture after increasing the pressure and the temperature to 200 bar and $60{ }^{\circ} \mathrm{C}$, respectively, but only for a short period. With time, the green precipitate is dissolved under these supercritical conditions. End products were obtained as pure crystalline materials. The presence of solid reagents was not observed in the X-ray profiles of the precipitated crystals (Fig. S1). Any possible excess 
of reagents was likely eliminated from the reactor during system depressurization, as indicated.

For the obtained products, the measured weight percentages of $\mathrm{C}, \mathrm{H}$ and $\mathrm{N}$ confirmed the expected stoichiometry (Table 1). The combination of $\mathrm{Cu}(\mathrm{hfacac})_{2}$ and $\mathrm{PhPy}$ or BzPy was attempted by using either the $\mathrm{scCO}_{2}$ route or conventional solvents. Similar compounds, either $\left[\mathrm{Cu}(\mathrm{hfacac})_{2}(\mathrm{PhPy})_{2}\right]$ or $\left[\mathrm{Cu}(\mathrm{hfacac})_{2}(\mathrm{BzPy})_{2}\right]$, were obtained using any of the tested precipitation techniques, according to characterization by powder XRD (Fig. 3 a, b). This result was further confirmed by elemental analysis (Table 1) and FT-IR (Fig. S2, supporting info). However, for $\left[\mathrm{Cu}(\mathrm{hfacac})_{2}(\mathrm{AcPy})_{2}\right]$ a different scenario was found, since the $\mathrm{scCO}_{2}$ route yielded a pure polymorph (namely $\alpha-\left[\mathrm{Cu}(\mathrm{hfacac})_{2}(\mathrm{PhPy})_{2}\right]$ ) (Fig. 3c), whereas the conventional route generated a mixture of two polymorphs, involving predominantly a different phase than the $\mathrm{scCO}_{2}$ precipitated product (namely $\beta$-[Cu(hfacac) $\left.\left.)_{2}(\mathrm{PhPy})_{2}\right]\right)$ mixed in a minor proportion with $\alpha-\left[\mathrm{Cu}(\mathrm{hfacac})_{2}(\mathrm{PhPy})_{2}\right]$ (Fig. 3d). $\operatorname{src}\left[\mathrm{Cu}(\mathrm{hfacac})_{2}(\mathrm{dPy})_{2}\right]$ and conv $\left.\left[\mathrm{Cu}(\mathrm{hfacac})_{2}(\mathrm{dPy})_{2}\right]\right)$ depicted a similar FT-IR (Fig. S2, supporting info) and composition (Table 1).

Additional X-ray diffractograms were obtained for samples taken at different stages in the pressurization/depressurization protocol. Thus, for the PhPy ligand, a sample was collected after treating the reagents mixture at 60 bar and $25^{\circ} \mathrm{C}$, i.e., in the liquid $\mathrm{CO}_{2}$ phase, for few minutes (sample $\left.\operatorname{lp}\left[\mathrm{Cu}(\mathrm{hfacac})_{2}(\mathrm{PhPy})_{2}\right]\right)$. XRD showed the formation of crystalline $\left.\left[\mathrm{Cu}(\mathrm{hfacac})_{2}(\mathrm{PhPy})_{2}\right]\right)\left(\right.$ Fig. S3). By stopping the process just after reaching 200 bar and $60{ }^{\circ} \mathrm{C}$ (sample sp[Cu(hfacac $\left.)_{2}(\mathrm{dPy})_{2}\right]$ ) a fine green powder was recovered. The peaks in the X-ray diffractogram demonstrated that the sample also consist in crystalline $\left[\mathrm{Cu}(\mathrm{hfacac})_{2}(\mathrm{PhPy})_{2}\right]$. (Fig. S3). Finally, and in order of obtaining large crystals, the fine green precipitate was allowed to redissolve in $\mathrm{scCO}_{2}$ at 200 bar and $60{ }^{\circ} \mathrm{C}$ during a period of time comprised 
between 40 and $180 \mathrm{~min}$, and the compounds were further crystallized by a controlled slow depressurization (samples $\operatorname{src}\left[\mathrm{Cu}(\mathrm{hfacac})_{2}(\mathrm{dPy})_{2}\right]$ ). During the gradual expansion of the supercritical solution, both density and solvent power decreased, leading to solute supersaturation. The solution can reach a state of high homogeneous supersaturation, since the propagation of induced pressure variation is extremely fast. Slow crystal growth leads to the formation of large crystals.

\subsection{Crystal structures}

The structures of the $\left[\mathrm{Cu}(\mathrm{hfacac})_{2}(\mathrm{PhPy})_{2}\right], \quad\left[\mathrm{Cu}(\mathrm{hfacac})_{2}(\mathrm{AcPy})_{2}\right]$ and $\left[\mathrm{Cu}(\text { hfacac })_{2}(\mathrm{BzPy})_{2}\right]$ adduct crystals have not been found described in the literature and, hence, they were solved in this study. For this reason, the precipitation of large crystals was attempted by slow recrystallization in either supercritical or solvent evaporation conditions. From them, green single crystals were studied by X-ray analysis.

All studied compounds (products in Fig. 1) are molecular complexes that crystallize in the monoclinic crystal system. The unsaturated coordination sphere of copper in the $\mathrm{Cu}(\mathrm{hfacac})_{2}$ precursor is completed by two pyridine-type donors occupying relative trans positions. This configuration is quite similar to the geometry described for $\left[\mathrm{Cu}(\mathrm{hfacac})_{2}\right]$ adducts with pyridine derivatives and other N-donor ligands, such as 3-cyanopyridine or pyrazine, ${ }^{36}$ 3-pyridyl-1-acetamidobenzene, ${ }^{37}$ isonicotinamide, ${ }^{38}$ cyanopyridine, ${ }^{39}$ N-tert-butylN-oxyamino-pyridine, 3-(N-tert-butyl-N-oxyamino-pyridine ${ }^{40}$ and imidazol, ${ }^{41}$ but different from the geometry found in $\left[\mathrm{Cu}(\mathrm{hfacac})_{2}(\mathrm{Py})_{2}\right],{ }^{42}$ in which the two pyridine ligands adopt a cis disposition. From the crystalline structure data, it was inferred that all the measured $\mathrm{Cu}-\mathrm{O}$ and $\mathrm{Cu}-\mathrm{N}$ bond distances are similar to other previously reported for $\mathrm{Cu}(\mathrm{hfacac})_{2}$ adducts with pyridine type ligands (Tables 4-5). The different $\mathrm{Cu}-\mathrm{O}$ bond lengths fall in the range 2.27$2.00 \AA$ and the $\mathrm{Cu}-\mathrm{N}$ bond distances are 2.04 and $2.01 \AA$, respectively. The electronic effects 
of the fluorine atoms in hexafluoroacetylacetonate compared with acetylacetonate in $\mathrm{Cu}(\mathrm{II})$ complexes have been used to determine the molecular and supramolecular structure of Cu(II) compounds. ${ }^{36}$ In a first approach, it was expected that the intermolecular interactions in these complexes build architectures with intrinsic open microcavities. ${ }^{43-46}$ However, none of the compounds studied showed a significant empty volume, as indicated by low temperature $\mathrm{N}_{2}$ adsorption measurements, since obtained specific surface area values were lower than $5 \mathrm{~m}^{2} \mathrm{~g}^{-1}$ for all the studied samples.

$\left[\mathbf{C u}(\mathbf{h f a c a c})_{2}(\mathbf{P h P y})_{2}\right]$. The structure was solved from a crystal obtained by evaporation of a concentrated solution of the precursors in a mixture of DCM and heptane. The structure is centrosymmetric (space group P21/c), with the copper atom located on the inversion center (Fig. 4). The pyridine ring is almost perpendicular to the plane containing the four oxygen atoms [83.2(1) ${ }^{\circ}$. The phenyl ring of PhPy ligand is twisted [37.4(1) $\left.{ }^{\circ}\right]$ with respect to the plane of the pyridine ring. The most relevant intermolecular interaction is between the adducts along b through two pairs of $\mathrm{O}(2) \cdots \mathrm{H}(7)$ contacts (2.62 $\AA$ ), involving the hydrogen in the meta position of the pyridine ring and the oxygen that shows the longer $\mathrm{Cu}-\mathrm{O}$ bond distance. In addition, each adduct interacts with two neighboring adducts in the c axis direction through $\mathrm{C}(1)-\mathrm{F}(2) \cdots \mathrm{C}(13)(3.07 \AA)$, connecting the hfacac ligand and the phenyl ring of the pyridine ligand. The combination of both mentioned intermolecular interactions defines two dimensional layers parallel to the bc plane. There are several C-F $\cdots \pi$ interactions that involve both the pyridine ring and the phenyl ring of neutral ligand, being the most intense $\mathrm{C}(5)-\mathrm{F}(5) \cdots \pi(\mathrm{py})[3.187(8) \AA]$, which reinforces the intermolecular link between molecules in the c direction. Some F $\cdots F$ interaction complete the network of intermolecular interactions.

$\left[\mathbf{C u}(\mathbf{h f a c a c})_{\mathbf{2}}(\mathbf{B z P y})_{2}\right]$. The structure was solved from a large crystal obtained in the conventional procedure from the evaporation of a concentrated solution in a mixture of DCM 
and heptane. As the PhPhy compound, the structure is centrosymmetric (space group P21/n) with the copper atom on the inversion center (Fig. 5) and the pyridine ligand almost perpendicular to the plane containing the four oxygen atoms [86.9(1) $\left.{ }^{\circ}\right]$. However, this compound shows fewer and weaker interatomic interactions than the $\left[\mathrm{Cu}(\mathrm{hfacac})_{2}(\mathrm{PhPy})_{2}\right]$ adduct. Each molecule interacts with the four nearest molecules through pairs of $\mathrm{H}(7) \cdots \mathrm{C}(17)$ contacts (2.86 $\AA$ ), which involves the hydrogen in the meta position of the pyridine ring, and a carbon atom of the phenyl ring (in ortho). The propagation of these interactions generates two dimensional layers parallel to the (10-1) plane. In addition, the interlayer interactions, involving $\mathrm{C}-\mathrm{F} \cdots \pi$ contacts that implicate exclusively the pyridine ring of the $\mathrm{BzPy}$, and $\mathrm{F} \cdots \mathrm{F}$ contacts, completes a tridimensional network of intermolecular interactions.

$\left[\mathbf{C u}(\mathbf{h f a c a c})_{2}(\mathbf{A c P y})_{2}\right]$ : This compound presents two polymorphs, $\alpha$ and $\beta$. Again, both structures are centrosymmetric (same space group, solved on $\mathrm{P} 21 / c$ and $\mathrm{P} 21 / n$ respectively) and have the copper atoms on the inversion centers (Fig. 6a and 6b).

$\boldsymbol{\alpha}$-[Cu(hfacac $\left.)_{2}(\mathbf{A c P y})_{2}\right]$. The structure was solved from a large crystal obtained by supercritical recrystallization. The pyridine ring is almost perpendicular to the plane containing the four oxygen atoms $\left[87.8(1)^{\circ}\right]$. The most intense intermolecular interactions involve the oxygen atom of the acetyl group of the pyridine ligand that interacts with one of the hydrogen atoms of the acetyl group of a closer molecule $\mathrm{O}(3) \cdots \mathrm{H}(12 \mathrm{~B})(2.53 \AA)$ and with one hydrogen atom of the aromatic ring $\mathrm{O}(3) \cdots \mathrm{H}(7)(2.61 \AA)$. The propagation of both contacts define layers reinforced also with intermolecular contacts between hydrogen atoms of the aromatic ring of the pyridine in meta position, and one oxygen atom of the hfacac ligand $\mathrm{O}(2) \cdots \mathrm{H}(9)(2.64 \AA)$ and also with the $\mathrm{C}(1)-\mathrm{F}(1) \cdots \pi(\mathrm{Py})$ [3.894(7) Å]. Shorter C(5)$\mathrm{F}(5) \cdots \pi(\mathrm{Py})[3.406(7) \AA]$ establish interlayer links.

$\boldsymbol{\beta}$-[Cu(hfacac $\left.)_{2}(\mathbf{A c P y})_{2}\right]$. This structure was solved from a large crystal obtained from the evaporation of a concentrated solution in a mixture of methanol and water. The structure 
contains two crystallographically independent $\left[\mathrm{Cu}(\mathrm{hfacac})_{2}(\mathrm{AcPy})_{2}\right]$ molecular complexes. The pyridine rings are almost perpendicular to the plane containing the four oxygen atoms $\left[85.9(2)^{\circ}\right.$ for $\mathrm{Cu}(1)$ and $89.3(2)^{\circ}$ for $\left.\mathrm{Cu}(2)\right]$ (Fig. 6b). In this polymorph, the strongest intermolecular interactions clearly define chains parallel to the a axis with short $F(1) \cdots C(45)$ contacts [3.06(3) $\AA$ ] between a fluorine atom and the ortho carbon of a pyridine ligand linked to the adjacent copper atom in the chain. This is associated by a short $\mathrm{H}(21) \cdots \mathrm{H}(45)$ contact $(2.10 \AA)$ that involves the hydrogen covalently linked to the former carbon atom and ortho hydrogen from the pyridine of the related molecule (the same that contains F1). Thus, in the chain each molecule is connected to the two closest ones by two pair of contacts. Besides, short C-F $\cdots \pi$ contacts strengthened the cohesion of the chains $[\mathrm{C}(4)-\mathrm{F}(1) \cdots \pi(\mathrm{Py}, \mathrm{N} 3), 3.18(3)$ $\AA ̊$ and C(13)-F(9) * $\pi(\mathrm{Py}, \mathrm{N} 1), 3.32(1) \AA ̊]$.

\subsection{Crystal morphology}

A deep study of crystal habit was performed for the $\left[\mathrm{Cu}(\mathrm{hfacac})_{2}(\mathrm{PhPy})_{2}\right]$ and $\left[\mathrm{Cu}(\mathrm{hfacac})_{2}(\mathrm{BzPy})_{2}\right]$ samples constituted by a single crystallized polymorph. Optical as well as electronic images were taken for this purpose.

For scr[Cu(hfacac $\left.)_{2}(\mathrm{PhPy})_{2}\right]$ sample, an initial process of homogeneous nucleation and precipitation was evidenced at depressurization pressures of ca. 120-100 bar (Fig. 2) by the sudden development of a myriad of small crystals in the bulk of the solution, with the appearance of thin flakes that slowly fall down with a kind of Brownian motion. A noteworthy amount of these flakes was still present on the wall of the reactor after system depressurization (Fig. 7a, red arrow). Further, the development of large acicular crystals was observed at pressures lower than 80 bar (Fig. 7a). These crystals were recovered after system depressurization. On the contrary, the isolated episode of homogeneous nucleation observed for the $\left[\mathrm{Cu}(\mathrm{hfacac})_{2}(\mathrm{PhPy})_{2}\right]$ product was not detected for the $\left[\mathrm{Cu}(\mathrm{hfacac})_{2}(\mathrm{BzPy})_{2}\right]$ material. 
In this case, residual small crystals were also not observed on the reactor wall (Fig. 7b). For scr $\left[\mathrm{Cu}(\mathrm{hfacac})_{2}(\mathrm{BzPy})_{2}\right]$ sample, large crystals were obtained, with a polyhedral habit and a more isometric aspect ratio than those involving the PhPy ligand (Fig. 7b).

For the $\left[\mathrm{Cu}(\mathrm{hfacac})_{2}(\mathrm{PhPy})_{2}\right]$ material, SEM images of the intermediate $\left.\mathrm{sp}\left[\mathrm{Cu}(\mathrm{hfacac})_{2}(\mathrm{PhPy})_{2}\right]\right)$ product indicates that the sample was constituted by dense crystals of sizes comprised between 10 and $40 \mu \mathrm{m}$ (Fig. 8a). Similar dense crystals were recrystallized following the conventional evaporation mode (sample conv[Cu(hfacac) $\left.)_{2}(\mathrm{PhPy})_{2}\right]$ ) (Fig. 8b). For the CSS recrystallized product (sample src $\left.\left[\mathrm{Cu}(\mathrm{hfacac})_{2}(\mathrm{PhPy})_{2}\right]\right)$, particles of several hundred microns with an extremely high aspect ratio were observed at low magnification (Fig. 8c). High magnification SEM analysis reveals a habit involving likely a layer-by-layer alignment, with steps in the micrometric height scale (Fig. 8d), coincident with the twodimensional organization in parallel layers described in its crystalline structure.

The longer dissolution time required to completely dissolve the $\mathrm{sp}\left[\mathrm{Cu}(\mathrm{hfacac})_{2}(\mathrm{PhPy})_{2}\right]$ product $(180 \mathrm{~min})$ after the initial precipitation period, in comparison with the rest of the studied materials (40 min), is indicative of lower solubility of this adduct in the $\mathrm{scCO}_{2}$ medium. This assessment is sustained by the crystal structure resolution data, in which it was shown that $\left[\mathrm{Cu}(\mathrm{hfacac})_{2}(\mathrm{PhPy})_{2}\right]$ has more and stronger interatomic interactions than the rest of the studied adducts, which would increase its dissolution energy. As a consequence, the adduct nucleates in an early stage during the depressurization process (ca. 120 bar), having the crystals longer times to grow, agglomerate and ripen. Large and well faceted polyhedral crystals were thus fully developed, showing different habits and a hollowness.

The observed morphology for $\operatorname{src}\left[\mathrm{Cu}(\mathrm{hfacac})_{2}(\mathrm{PhPy})_{2}\right]$ crystals could be described by a kinetic model of growth by plate-by-plate oriented attachment, whereby primary flake-like platelets attach to one another in an irreversible and highly oriented fashion to produce new 
large single crystals or pseudocrystals with polyhedral facets. ${ }^{47-49}$ This type of aggregation has the ability of stabilization of the crystallographic planes that bordered the crystalline products, while the global crystal orientations are still strictly maintained in a single-crystalline, generally hollow, structure. For this sample, a hole, in different stages of development, was almost found on every complete crystal. Fig. 9a-f shows images captured for tubes showing different morphologies, from incipient concave tips to perfect hollow tubes. This unique crystal habit is described for systems in which the oriented attachment mechanism works together with Ostwald ripening by anisotropic dissolution. ${ }^{50,51}$ Often, imperfect oriented attachment of primary crystals occurs, predominantly, at the central part of the pseudocrystal, which induces dissolution of the crystal core forming a concavity and growth of the sidewalls. The concavity of the tip surface continuously increases by dissolution, and finally the rod-like crystals are transformed into microtubes. By lowering the supersaturation, as the experiment progressed and the reagents are consumed, Ostwald ripening could become the predominant mechanism of hollow crystal development. Similar hollow hybrid wires have been prepared by a microfluidic approach and proposed as one-dimensional conductive devices. ${ }^{52}$

The crystals obtained from the BzPy reagent have a different morphology than the previously described hollow structure for PhPy. The $\operatorname{src}\left[\mathrm{Cu}(\mathrm{hfacac})_{2}(\mathrm{BzPy})_{2}\right]$ crystals obtained by CSS have sizes between 200 and $500 \mu \mathrm{m}$, an aspect ratio lower than 5 and a polyhedral hoppered habit (Fig. 10a). The concentration gradients arising during the slow depressurization process carried out in the CSS method drive the formation of hopper-shaped crystals. ${ }^{53}$ As a result, the edges of the hoppered crystals are fully developed, but the interior spaces are not filled in. In general, hoppering occurs when two-dimensional nucleation is higher along the edges of the crystal than near the face center. The interior shows crystals with the form characteristic of the large crystal, being miniature versions of it. Crystals seems to grow layer wise forming crystals bounded by faces (Fig. 10b). Similar sprouting of plates, 
the occurrence of hopper growth and the stepped structure on the plates (Fig. 10c) has been previously described for naphthalene large crystals grown in $\mathrm{scCO}_{2}$ using a similar $\mathrm{CSS}$ procedure. ${ }^{54}$ Crystals obtained by fast precipitation in $\mathrm{scCO}_{2}$ at 200 bar (sample sp[Cu(hfacac $\left.\left.)_{2}(\mathrm{BzPy})_{2}\right]\right)$ were well faceted polyhedra (Fig. 10d), with a dense structure and relatively small size $(3-50 \mu \mathrm{m})$. As well, crystals obtained by conventional evaporation (sample conv[Cu(hfacac) $\left.)_{2}(\mathrm{BzPy})_{2}\right]$ ) (Fig. 10e) had similar morphology and size to the $\mathrm{scCO}_{2}$ fast precipitated product, although they showed a narrower particle size distribution (20-50 $\mu \mathrm{m})$. In general, facet growth is given in an environment with negligible bulk-diffusion barrier, i.e., in a kinetic regime, which results in faceted small crystals, while hopper growth is observed in systems with a significant bulk-diffusion barrier, i.e., in the diffusion regime. Crystals obtained following the conventional or straight $\mathrm{scCO}_{2}$ precipitation method correspond to those expected from a kinetic control, while crystals obtained in the CSS method are consistent with habits anticipated in a diffusion regime.

The $\operatorname{src}\left[\mathrm{Cu}(\mathrm{hfacac})_{2}(\mathrm{AcPy})_{2}\right]$ sample, containing the pure $\alpha$-polymorph, presented hollowness as shown in Fig. S4 (supporting info). In this case, large hollow rectangular prisms can be also observed, as in the case of $\operatorname{src}\left[\mathrm{Cu}(\mathrm{hfacac})_{2}(\mathrm{PhPy})_{2}\right]$, with holes of different diameter as a function of the growth stage of the crystals. Moreover, as in the case of the PhPy ligand, the prismatic microtubes also showed sharp edges that become slightly rounded as the thickness of the crystal increases.

Among the studies carried out in supercritical fluid crystallization processes, very little examples of hollow structures are found, being the most documented those formed by mesoporous hollow spheres prepared from supercritical $\mathrm{CO}_{2} /$ water systems ${ }^{55}$ or by using strategies involving template methods, as in the case of micrometric hollow fibers. ${ }^{56}$ From all of the reported structures, only one case of rectangular hollow tubes, similar to crystals in this work, using supercritical water was found. ${ }^{57}$ The micrometric intra-particle voids would have 
a direct impact in crystal properties, primarily by facilitating the diffusion of molecules. Certainly, materials with hollow interiors have attracted great attention in recent years due to their widespread potential applications in many fields, e.g., new materials for sensors/probes, drug-delivery carriers, biomedical diagnosis agents, catalysts for size-selective reactions, etc. $^{58}$

\section{Conclusions}

This work demonstrates the ability of $\mathrm{scCO}_{2}$ to produce crystalline coordination compounds. The use of $\mathrm{scCO}_{2}$ : has led to the precipitation of pure polymorphs of $\left[\mathrm{Cu}(\mathrm{hfacac})_{2}(\mathrm{PhPy})_{2}\right],\left[\mathrm{Cu}(\mathrm{hfacac})_{2}(\mathrm{BzPy})_{2}\right]$ and $\alpha-\left[\mathrm{Cu}(\text { hfacac })_{2}(\mathrm{AcPy})_{2}\right]$. Moreover, in the case of samples supercritically recrystallized using either PhPy or AcPy ligand, prismatic hollow microtube morphologies were observed, whereas by using organic conventional solvents the same materials yielded compact microstructures. The resolution of the obtained polymorphs showed structures consisting of discrete molecules connected thought intermolecular interactions growing towards bidimensional arrangements.

\section{Acknowledgments}

This work was partially financed by the Spanish National Plan of Research CTQ2014-56324 and Severo Ochoa SEV-2015-0496, and by the Generalitat de Catalunya 2014SGR377. A. López-Periago acknowledges the RyC-2012-11588 contract. ALBA synchrotron is acknowledged for the provision of beamtime. 


\section{References}

(1) Blake, A.J.; Champness, N.R.; Hubberstey, P.; Li, W.S.; Withersby, M.A.; Schroder, M. Coord. Chem. Rev. 1999, 183, 117-138.

(2) Czaja, A.U.; Trukhan, N.; Müller, U. Chem. Soc. Rev. 2009, 38, 1284-1293.

(3) Chemical Synthesis using Supercritical Fluids; Jessop, P.I., Leitner, W., Eds.; WileyVCH: Weinheim, 1999.

(4) Lopez-Periago, A.M.; Garcia-Gonzalez, C.A.; Domingo, C. Chem. Commun., 2010, 46, 4315-4317.

(5) Supercritical Fluid Nanotechnology: advances and applications in composites and hybrid nanomaterials, Domingo, C.; Subra, P., Eds.; Pan Satanford Publising, 2015.

(6) Martín, A.; Cocero. M. J. Advanced Drug Delivery Reviews 2008, 60, 339-50.

(7) High Pressure Process technology: fundamentals and applications, A. Bertucco, G. Vetter, Eds. Industrial Chemistry Library, Vol. 9 Elsevier Science; 2001.

(8) Tai, C.Y.; Cheng, C-S. AIChE J., 1995, 41, 2227-2236.

(9) Tavana, A. Randolph, A.D. AIChE J., 1989, 35, 1625-1630.

(10) Khrustalev, V.N.; Nikitin, L.N.; Vasilkov, A.Y.; Khokhlov, A.R. Russ. Chem. Bulletin Int. Ed., 2006, 55, 576-578.

(11) Gupta, R. B.; Shim, J.-J. Solubility in Supercritical Carbon Dioxide; CRC Press: New York, 2007.

(12) Pradela, L.; Rodrigues, M.A.; Velaga, S.P.; Matos, H.A.; Azevedo, E. G. Eur. J. Pharm. Sci., 2009, 38, 9-17.

(13) Padrela, L.; Rodrigues, M.; Tiago, J.; Velaga, S.; Matos, H.; de Azevedo E. Cryst. Growth Des. 2015, 15, 3175-3181.

(14) Neurohr, C.; Revelli, A.-L.; Billoc, P.; Marchivie, M.; Lecomte, S.; Laugier, S.; Massip, S.; Subra-Paternault, P.; J. Supercrit. Fluids, 2013, 83, 78-85. 
(15) McCabe, W.; Smith, J.; Harriott, P. Unit Operations of Chemical Engineering' McGrawHill, New York, 2000.

(16) Squires, T.G.; Venier, C.G.; Hunt, J.D.; Shei, J.C.; Smith, F.F. Fuel 1982, 61, 11701172.

(17) Murzin, A.A.; Babain, V.A.; Shadrin, A.Y.; Smirnov, I.V.; Lumpov, A.A.; Gorshkov, N.I.; Miroslavov, A.E.; Muradymov, M.Z. Radiochemistry 2001, 43, 177-182.

(18) Ingrosso, F.; Altarsha, M.; Dumarçay, F.; Kevern, G.; Barth, D.; Marsura, A.; RuizLópez, M.F. Chem. Eur. J. 2016, doi: 10.1002/chem.201503780.

(19) Shum,W.W.; Schaller, J.N.; Miller, J.S. J. Phys. Chem. C 2008, 112, 7936-7941.

(20) Santini, C.; Pellei, M.; Gandin, V.; Porchia, M.; Tisato, F.; Marzano, C. Chem. Rev. 2014, 114, 815-862.

(21) Tabernero, A.; Martín del Valle, E.M.; Galán, M.A. Chem. Eng. Process. 2012, 60, 925.

(22) Eddleston, M.D.; Jones, W. Cryst. Growth Des, 2010, 10, 365-370.

(23) Rius, J. Acta Cryst., 1993, A49, 406-409

(24) Sheldrick, G. M. Acta Cryst., 2015, C71, 3-8.

(25) Müller, P. Cryst. Rev., 2009, 15, 57-83.

(26) Fauth, F., Peral, I., Popescu, C., Knapp, M. Powder Diffr., 2013, 28, S360-S370.

(27) Teoh, W.H.; Mammucari, R.; Foster, N.R. J. Organometallic Chem. 2013, 724, 102-116.

(28) Lagalante, A.F.; Hansen, B.N.; Bruno, T.J.; Sievers, R.E. Inorg. Chem., 1995, 34, 5781.

(29) Inada, Y.; Sato, H.; Liu, S.H., Horita, T.; Funahashi, S. J. Phys. Chem. A 2003, 107, $1525-1531$.

(30) Blackburn, J. M.; Long, D. P.; Cabanas, A.; Watkins, J. J. Science 2001, 294, 141-45.

(31) Kondoh, E.; Kato, H. Microelect. Eng., 2002, 64, 495-99. 
(32) Garriga, R.; Pessey, V.; Weill, F.; Chevalier, B.; Etourneau, J.; Cansell, F. J. Supercritical Fluids 2001, 20, 55-63.

(33) López-Periago, A.; Vallcorba, O.; Frontera, C.; Domingo, C.; Ayllón, J.A. Dalton Trans., 2015, 44, 7548-7553.

(34) Bessel, C.; Denison, G.M.; DeSimone, J.M.; DeYoung, J.; Gross, S.; Schauer, C.K.; Visintin, P.M. J. Am. Chem. Soc., 2003, 125, 4980-81.

(35) Murzin, A.A.; Babain, V.A.; Shadrin, A.Y.; Kamachev, V.A.; Strelkov, S.A. Radiochemistry, 2003, 45, 131-34.

(36) Dong, Y.-B.; Smith, M.D.; Layland, R.C.; zur Loye, H.-C. Inorg. Chem. 1999, 38, 50275033.

(37) Aakeröy, C.B.; Hussain, I.; Forbes, S.; Desper, J. Aust. J. Chem. 2009, 62, 899-908.

(38) Germán-Acacio, J.M.; Hernández-Ortega, S.; Aakeröy, C.B.; Valdés-Martínez, J. Inorg. Chim. Acta 2009, 362, 4087-4090.

(39) Lee, B.-W.; Twamley, B.; Shreeve, J. M. J.Fluorine Chem., 2001, 108, 111-116.

(40) Ishimaru, Y.; Kitano, M.; Kumada, H.; Koga, N.; Iwamura, H. Inorg. Chem. 1998, 37, 2273-2280.

(41) Delgado, S.; Muñoz, A.; Medina, M.E.; Pastor, C.J. Inorg. Chim. Acta 2006, 359, 109117.

(42) Pradilla-Sorzano J.; Fackler, J.P. Inorg. Chem., 1973, 12, 1174-82.

(43) Yu, F.; Li, D.-D.; Cheng, L.; Yin, Z.; Zeng, M.-H.; Kurmoo, M. Inorg. Chem. 2015, 54, $1655-1660$.

(44) Leigh Loots, L.; O’Connor, J.P.;le Roex, T., Haynes, D.A. Cryst. Growth Des. 2015, 15, pp 5849-5857.

(45) Soldatov, D.V.; Enright, G.D.; Ripmeester, J.A. Chem. Mater., 2002, 14, 348-356.

(46) Springsteen, C.H.; Sweeder, R.D.; LaDuca, R.L. Cryst. Growth Des. 2006, 6, 2308-2314. 
(47) Zhang, Q.; Liu, S-J.; Yu, S.H. J. Mater. Chem. 2009, 19, 191-207.

(48) Niederberger, M.; Cölfen, H. Phys. Chem. Chem. Phys., 2006, 8, 3271-3287.

(49) Zeng, H. C. J. Mater. Chem., 2001, 21, 7511-7526.

(50) Zeng, H.C. Curr. Nanosci., 2007, 3, 177-181.

(51) Greer, H.F. Mater. Sci. Tech. 2014, 30, 611-626.

(52) Puigmartí-Luis, J.; Schaffhauser, D.; Burg, B.R.; Dittrich, P.S. Adv. Mater., 2010, 22, 2255-2259.

(53) Campione, M.; Ruggerone, R.; Tavazzi, S.; Moret, M. J. Mater. Chem., 2005, 15, 24372443.

(54) Tai, C. Y.; Cheng. C. S., Chem.Eng. Res. \& Design 1997, 75, 228-32.

(55) Wang J.; ,Xia, Y.; Wang W.; Poliakoff M.; Mokaya R. J. Mater. Chem., 2006,16, 17511756.

(56) Xu Q.; Li J.; Peng Q.; Wu L.; Li S. Mater. Sc. Eng. B Adv. 2006, 127, 212-217.

(57) Niwa, K.; Taguchi, T.; Tokunaga, T.; Hasegawa, M. Cryst. Growth Des. 2011, 11, 4427443.

(58) Lou, X.W.D.; Archer, L.A.; Yang, Z. Adv. Mater. 2008, 20, 3987-4019. 


\section{For Table of Contents use Only}

Hollow microcrystals of copper hexafluoroacetylacetonate-pyridine derivative adducts via supercritical $\mathrm{CO}_{2}$ recrystallization.

Ana López-Periago, Oriol Vallcorba, Concepción Domingo and José A. Ayllón

\section{Table of Contents Graphic}

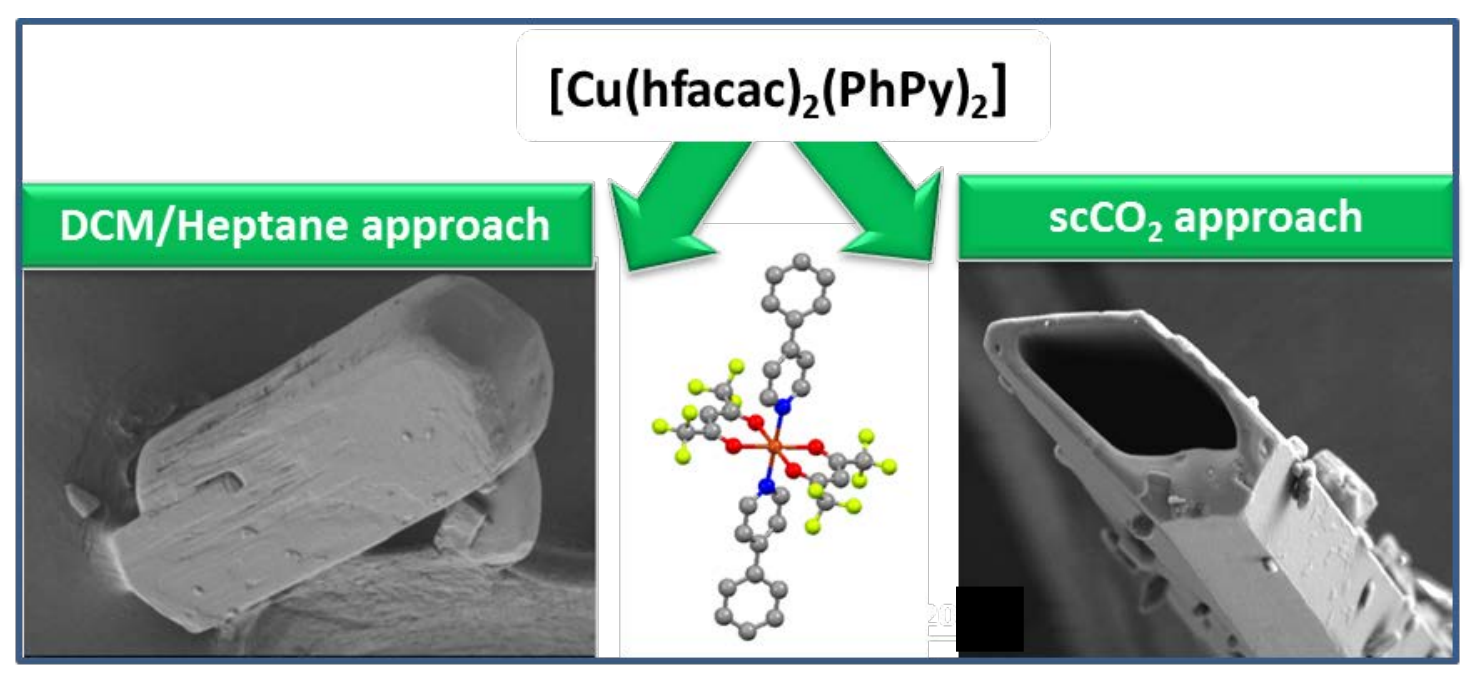

\section{Synopsis}

The use of $\mathrm{scCO}_{2}$ for the recrystallization of $\left[\mathrm{Cu}(\mathrm{hfacac})_{2}(\mathrm{dPy})_{2}\right]$ adducts produces samples with prismatic hollow microtube morphologies, whereas conventional solvents yield compact microstructures. For $\left[\mathrm{Cu}(\mathrm{hfacac})_{2}(\mathrm{AcPy})_{2}\right]$, $\mathrm{scCO}_{2}$ allows the crystallization of a pure polymorph, while the conventional solvents trials yield a mixture of two polymorphs. 
Table 1. Calculated and experimentally measured $\mathrm{C}, \mathrm{H}$ and $\mathrm{N}$ weight percentages for the synthesized samples either by supercritical (src) or conventional (conv) route.

\begin{tabular}{lccc}
\hline Sample & $\% \mathrm{C}$ & $\% \mathrm{H}$ & $\% \mathrm{~N}$ \\
\hline calculated $\left[\mathrm{Cu}(\mathrm{hfacac})_{2}(\mathrm{PhPy})_{2}\right]$ & 48.77 & 2.56 & 3.55 \\
sample scr-[Cu(hfacac $\left.)_{2}(\mathrm{PhPy})_{2}\right]$ & 48.91 & 2.52 & 3.50 \\
sample conv-[Cu(hfacac $\left.)_{2}(\mathrm{PhPy})_{2}\right]$ & 49.02 & 2.49 & 3.50 \\
& & & \\
calculated $\left[\mathrm{Cu}(\mathrm{hfacac})_{2}(\mathrm{BzPy})_{2}\right]$ & 50.04 & 2.96 & 3.43 \\
sample scr-[Cu(hfacac $\left.)_{2}(\mathrm{BzPy})_{2}\right]$ & 50.40 & 2.95 & 3.32 \\
sample conv-[Cu(hfacac $\left.)_{2}(\mathrm{BzPy})_{2}\right]$ & 50.33 & 2.94 & 3.36 \\
& & & \\
calculated $\left[\mathrm{Cu}(\mathrm{hfacac})_{2}(\mathrm{AcPy})_{2}\right]$ & 40.04 & 2.24 & 3.89 \\
sample scr-[Cu(hfacac $\left.)_{2}(\mathrm{AcPy})_{2}\right]$ & 40.14 & 2.22 & 3.79 \\
sample conv-[Cu(hfacac $\left.)_{2}(\mathrm{AcPy})_{2}\right]$ & 40.29 & 2.23 & 3.80 \\
\hline
\end{tabular}


Table 2. Summary of crystallographic data for [Cu(hfacac $\left.)_{2}(\mathrm{PhPy})_{2}\right]$ and $\left[\mathrm{Cu}(\mathrm{hfacac})_{2}(\mathrm{BzPy})_{2}\right]$.

\begin{tabular}{|c|c|c|}
\hline & {$\left[\mathrm{Cu}(\mathrm{hfacac})_{2}(\mathrm{PhPy})_{2}\right]$} & {$\left[\mathrm{Cu}(\mathrm{hfacac})_{2}(\mathrm{BzPy})_{2}\right]$} \\
\hline Molecular Formula & $\mathrm{C}_{32} \mathrm{H}_{20} \mathrm{Cu}_{1} \mathrm{~F}_{12} \mathrm{~N}_{2} \mathrm{O}_{4}$ & $\mathrm{C}_{34} \mathrm{H}_{24} \mathrm{Cu}_{1} \mathrm{~F}_{12} \mathrm{~N}_{2} \mathrm{O}_{4}$ \\
\hline Formula weight & 788.04 & 816.09 \\
\hline $\begin{array}{l}\text { Crystal system, space } \\
\text { group }\end{array}$ & Monoclinic, P $2{ }_{1} / c$ & Monoclinic, P 2 $/ n$ \\
\hline \multicolumn{3}{|l|}{ Unit cell dimensions } \\
\hline$a(\AA)$ & 11.7558(6) & $8.9806(5)$ \\
\hline$b(\AA)$ & $7.7410(4)$ & $19.0258(10)$ \\
\hline$c(\AA)$ & $18.3815(9)$ & $10.3366(5)$ \\
\hline$\alpha\left({ }^{\circ}\right)$ & 90 & 90 \\
\hline$\beta\left(^{\circ}\right)$ & $96.602(1)$ & 101.519(1) \\
\hline$\gamma\left({ }^{\circ}\right)$ & 90 & 90 \\
\hline $\mathrm{V}\left(\AA^{3}\right)$ & 1661.65(15) & $1730.57(16)$ \\
\hline $\mathrm{Z}$ (according to MF) & 2 & 2 \\
\hline Dcalc $\left(\mathrm{g} \mathrm{cm}^{-3}\right)$ & 1.575 & 1.556 \\
\hline Temperature (K) & 298 & 298 \\
\hline Wavelength $(\AA)$ & 0.71073 & 0.71073 \\
\hline$\mu\left(\mathrm{mm}^{-1}\right)$ & 0.764 & 0.737 \\
\hline $\mathrm{F}(000)$ & 790 & 822 \\
\hline Crystal size $\left(\mathrm{mm}^{3}\right)$ & $0.50 \times 0.28 \times 0.25$ & $0.76 \times 0.46 \times 0.26$ \\
\hline hkl ranges & $\begin{array}{l}-15 \leq \mathrm{h} \leq 15 \\
-10 \leq \mathrm{k} \leq 10 \\
-24 \leq \mathrm{l} \leq 23\end{array}$ & $\begin{array}{l}-11 \leq \mathrm{h} \leq 12 \\
-24 \leq \mathrm{k} \leq 24 \\
-13 \leq \mathrm{l} \leq 13\end{array}$ \\
\hline$\theta$ Range $\left(^{\circ}\right)$ & 1.74 to 28.73 & 2.14 to 28.67 \\
\hline $\begin{array}{l}\text { Reflections } \\
\text { collected/unique/[Rint] }\end{array}$ & $12772 / 4038[0.0204]$ & $13479 / 4113[0.0176]$ \\
\hline Completeness to $\theta(\%)$ & $93.8 \%\left(\theta=28.73^{\circ}\right)$ & $92.3 \%\left(\theta=28.67^{\circ}\right)$ \\
\hline Absorption correction & $\begin{array}{l}\text { Semiemprirical, } \\
\text { SADABS }^{\mathrm{a}}\end{array}$ & $\begin{array}{l}\text { Semiemprirical, } \\
\text { SADABS }^{\mathrm{a}}\end{array}$ \\
\hline Data/parameters/restraints & $4038 / 288 / 126$ & $4113 / 297 / 126$ \\
\hline Goodness-of-fit on $\mathrm{F}^{2}$ & 1.027 & 1.019 \\
\hline $\begin{array}{l}\text { Goodness-of-fit on } \mathrm{F}^{2} \\
\text { (excluding restraints) }\end{array}$ & 1.052 & 1.035 \\
\hline Final $\mathrm{R}$ indices $[\mathrm{I}>2 \sigma(\mathrm{I})]$ & $\begin{array}{l}\mathrm{R}_{1}=0.0348 \\
\mathrm{wR}_{2}=0.0952\end{array}$ & $\begin{array}{l}\mathrm{R}_{1}=0.0352 \\
\mathrm{wR}_{2}=0.0959\end{array}$ \\
\hline R indices (all data) & $\begin{array}{l}\mathrm{R}_{1}=0.0449 \\
\mathrm{wR}_{2}=0.1013\end{array}$ & $\begin{array}{l}\mathrm{R}_{1}=0.0528 \\
\mathrm{wR}_{2}=0.1066\end{array}$ \\
\hline $\begin{array}{l}\text { Largest diff. peak and hole } \\
\left(\mathrm{e} \AA^{-3}\right)\end{array}$ & $0.25,-0.20$ & $0.25,-0.16$ \\
\hline
\end{tabular}

${ }^{\mathrm{a}}$ Bruker AXS Inc., Madison, Wisconsin, USA 
Table 3. Summary of crystallographic data for $\alpha-\left[\mathrm{Cu}(\mathrm{hfacac})_{2}(\mathrm{AcPy})_{2}\right]$, and $\beta$ [Cu(hfacac $\left.)_{2}(\text { AcPy })_{2}\right]$.

\begin{tabular}{|c|c|c|}
\hline & $\alpha-\left[\mathrm{Cu}(\mathrm{hfacac})_{2}(\mathrm{AcPy})_{2}\right]$ & $\beta$-[Cu(hfacac $\left.)_{2}(\mathrm{AcPy})_{2}\right]$ \\
\hline Molecular Formula & $\mathrm{C}_{24} \mathrm{H}_{16} \mathrm{Cu}_{1} \mathrm{~F}_{12} \mathrm{~N}_{2} \mathrm{O}_{6}$ & $\mathrm{C}_{24} \mathrm{H}_{16} \mathrm{Cu}_{1} \mathrm{~F}_{12} \mathrm{~N}_{2} \mathrm{O}_{6}$ \\
\hline Formula weight & 719.93 & 719.93 \\
\hline $\begin{array}{l}\text { Crystal system, } \\
\text { space group }\end{array}$ & Monoclinic, $\mathrm{P} 2{ }_{1} / c$ & Monoclinic, $\mathrm{P} 2{ }_{1} / n$ \\
\hline \multicolumn{3}{|l|}{ Unit cell dimensions } \\
\hline$a(\AA)$ & $9.6460(7)$ & 14.2451(9) \\
\hline$b(\AA)$ & $7.8407(5)$ & $9.8092(6)$ \\
\hline$c(\AA)$ & $19.9690(14)$ & $21.0465(13)$ \\
\hline$\alpha\left(^{\circ}\right)$ & 90 & 90 \\
\hline$\beta\left(^{\circ}\right)$ & $102.890(1)$ & $102.190(1)$ \\
\hline$\gamma\left(\left(^{\circ}\right)\right.$ & 90 & 90 \\
\hline $\mathrm{V}\left(\AA^{3}\right)$ & $1472.22(18)$ & 2074.6(3) \\
\hline $\mathrm{Z}$ (according to MF) & 2 & 4 \\
\hline Dcalc $\left(\mathrm{g} \mathrm{cm}^{-3}\right)$ & 1.624 & 1.664 \\
\hline Temperature (K) & 298 & 298 \\
\hline Wavelength $(\AA)$ & 0.71073 & 0.71073 \\
\hline$\mu\left(\mathrm{mm}^{-1}\right)$ & 0.858 & 0.879 \\
\hline $\mathrm{F}(000)$ & 718 & 1436 \\
\hline Crystal size $\left(\mathrm{mm}^{3}\right)$ & $0.85 \times 0.07 \times 0.06$ & $0.68 \times 0.11 \times 0.07$ \\
\hline hkl ranges & $\begin{array}{l}-12 \leq \mathrm{h} \leq 12 \\
-10 \leq \mathrm{k} \leq 10 \\
-25 \leq \mathrm{l} \leq 25\end{array}$ & $\begin{array}{l}-18 \leq \mathrm{h} \leq 18 \\
-13 \leq \mathrm{k} \leq 12 \\
-27 \leq \mathrm{l} \leq 27\end{array}$ \\
\hline$\theta$ Range $\left(^{\circ}\right)$ & 2.10 to 28.77 & 1.58 to 28.92 \\
\hline $\begin{array}{l}\text { Reflections } \\
\text { collected/unique/[Rint] }\end{array}$ & $11426 / 3595$ [0.0394] & $22079 / 6923$ [0.0747] \\
\hline Completeness to $\theta(\%)$ & $93.9 \%\left(\theta=28.77^{\circ}\right)$ & $91.2 \%\left(\theta=28.92^{\circ}\right)$ \\
\hline Absorption correction & $\begin{array}{l}\text { Semiemprirical, } \\
\text { SADABS }^{\mathrm{a}}\end{array}$ & $\begin{array}{l}\text { Semiemprirical, } \\
\text { SADABS }^{\mathrm{a}}\end{array}$ \\
\hline Data/parameters/restraints & $3595 / 226 / 126$ & $6923 / 523 / 396$ \\
\hline Goodness-of-fit on $\mathrm{F}^{2}$ & 1.021 & 0.944 \\
\hline $\begin{array}{l}\text { Goodness-of-fit on } \mathrm{F}^{2} \\
\text { (excluding restraints) }\end{array}$ & 1.070 & 0.982 \\
\hline Final $R$ indices $[\mathrm{I}>2 \sigma(\mathrm{I})]$ & $\begin{array}{l}\mathrm{R}_{1}=0.0519 \\
\mathrm{wR}_{2}=0.1293\end{array}$ & $\begin{array}{l}\mathrm{R}_{1}=0.0554 \\
\mathrm{wR}_{2}=0.1345\end{array}$ \\
\hline $\mathrm{R}$ indices (all data) & $\begin{array}{l}\mathrm{R}_{1}=0.0875 \\
\mathrm{wR}_{2}=0.1472\end{array}$ & $\begin{array}{l}\mathrm{R}_{1}=0.1505 \\
\mathrm{wR}_{2}=0.1883\end{array}$ \\
\hline $\begin{array}{l}\text { Largest diff. peak and hole } \\
\left(\mathrm{e} \AA^{-3}\right)\end{array}$ & $0.34,-0.33$ & $0.42,-0.43$ \\
\hline
\end{tabular}

${ }^{a}$ Bruker AXS Inc., Madison, Wisconsin, USA 
Table 4. Selected bond distances and angles around $\mathrm{Cu}$ atom for $\left[\mathrm{Cu}(\mathrm{hfacac})_{2}(\mathrm{dPy})_{2}\right](\mathrm{d}=\mathrm{Ph}$, $\mathrm{Bz}, \mathrm{Ac}$ ) compounds.

\begin{tabular}{|c|c|c|c|c|}
\hline & $\mathbf{d}=\mathbf{P h}$ & $\mathbf{d}=\mathbf{B z}$ & $\mathrm{d}=\mathrm{Ac}(\alpha)$ & $\mathrm{d}=\mathrm{Ac}(\boldsymbol{\beta})$ \\
\hline \multicolumn{5}{|l|}{ Bond distances $(\AA)$} \\
\hline $\mathrm{Cu}(1)-\mathrm{O}(1)$ & $2.0025(12)$ & $2.1101(15)$ & $2.002(2)$ & $2.198(3)$ \\
\hline $\mathrm{Cu}(1)-\mathrm{O}(2)$ & $2.2725(13)$ & $2.1533(14)$ & 2. 253(3) & 2.041(3) \\
\hline $\mathrm{Cu}(1)-\mathrm{N}(1)$ & $2.0262(13)$ & $2.0140(15)$ & 2. 041(3) & $2.023(3)$ \\
\hline $\mathrm{Cu}(2)-\mathrm{O}(5)$ & & & & $2.033(3)$ \\
\hline $\mathrm{Cu}(2)-\mathrm{O}(6)$ & & & & $2.227(3)$ \\
\hline $\mathrm{Cu}(2)-\mathrm{N}(3)$ & & & & $2.020(3)$ \\
\hline \multicolumn{5}{|l|}{ Bond Angles $\left({ }^{\circ}\right)^{a}$} \\
\hline $\mathrm{O}(1)-\mathrm{Cu}(1)-\mathrm{O}(2)$ & $86.66(4)$ & $87.70(5)$ & $87.25(8)$ & $88.17(11)$ \\
\hline $\mathrm{O}(1)-\mathrm{Cu}(1)-\mathrm{N}(1)$ & $89.70(5)$ & $89.72(6)$ & 89.74(9) & $89.48(11)$ \\
\hline $\mathrm{N}(1)-\mathrm{Cu}(1)-\mathrm{O}(2)$ & $88.73(5)$ & $89.21(6)$ & $88.55(10)$ & 89.56(11) \\
\hline $\mathrm{O}(5)-\mathrm{Cu}(1)-\mathrm{O}(6)$ & & & & $86.87(11)$ \\
\hline $\mathrm{O}(5)-\mathrm{Cu}(1)-\mathrm{N}(3)$ & & & & $88.94(12)$ \\
\hline $\mathrm{O}(6)-\mathrm{Cu}(1)-\mathrm{N}(3)$ & & & & $89.48(12)$ \\
\hline
\end{tabular}


Table 5. Selected intermolecular interactions for $\left[\mathrm{Cu}(\mathrm{hfacac})_{2}(\mathrm{dPy})_{2}\right](\mathrm{d}=\mathrm{Ph}, \mathrm{Bz}, \mathrm{Ac})$. For $\pi$ interactions the centroid of the ring is considered if no atom is specified. All distances in Angstrom ( $\AA$ ).

\begin{tabular}{|c|c|c|c|}
\hline \multicolumn{2}{|c|}{$\left[\mathrm{Cu}(\mathrm{hfacac})_{2}(\mathrm{PhPy})_{2}\right]$} & \multicolumn{2}{|c|}{$\left[\mathrm{Cu}(\mathrm{hfacac})_{2}(\mathrm{BzPy})_{2}\right]$} \\
\hline $\mathrm{O}(2) \cdots \mathrm{H}(7)$ & 2.62 & $\mathrm{H}(7) \cdots \mathrm{C}(17)$ & 2.86 \\
\hline $\mathrm{F}(2) \cdots \mathrm{C}(13)$ & $3.069(2)$ & $F(1) \cdots C(13)$ & $3.168(10)$ \\
\hline $\mathrm{C}(5)-\mathrm{F}(5) \cdot \pi(\mathrm{Py})$ & $3.187(8)$ & $\mathrm{C}(1)-\mathrm{F}(3 \mathrm{~B}) \cdot \pi(\mathrm{Py})$ & $3.350(11)$ \\
\hline $\mathrm{C}(1)-\mathrm{F}(2 \mathrm{~B}) \cdot \pi(\mathrm{Ph})$ & $3.413(8)$ & $\mathrm{C}(1)-\mathrm{F}(2) \cdots \pi(\mathrm{Py})$ & 3.548(13) \\
\hline $\mathrm{C}(1)-\mathrm{F}(3) \cdots \pi(\mathrm{Ph})$ & $3.766(11)$ & $\mathrm{F}(1 \mathrm{~B}) \cdots \mathrm{F}(5 \mathrm{~B})$ & $2.67(3)$ \\
\hline $\mathrm{C}(5)-\mathrm{F}(6 \mathrm{~B}) \cdot \pi(\mathrm{Py})$ & $3.679(16)$ & & \\
\hline $\mathrm{C}(5)-\mathrm{F}(4 \mathrm{~B}) \cdot \pi(\mathrm{Py})$ & $3.807(16)$ & & \\
\hline $\mathrm{F}(3 \mathrm{~B}) \cdots \mathrm{F}(4)$ & $2.613(16)$ & & \\
\hline$F(4 B) \cdots F(5 B)$ & $2.607(18)$ & & \\
\hline \multicolumn{2}{|c|}{$\alpha-\left[\mathrm{Cu}(\mathrm{hfacac})_{2}(\mathrm{AcPy})_{2}\right]$} & \multicolumn{2}{|c|}{$\beta-\left[\mathrm{Cu}(\mathrm{hfacac})_{2}(\mathrm{AcPy})_{2}\right]$} \\
\hline $\mathrm{O}(3) \cdots \mathrm{H}(12 \mathrm{~B})$ & 2.53 & $F(1) \cdots C(45)$ & $3.06(3)$ \\
\hline $\mathrm{H}(7) \cdots \mathrm{O}(3)$ & 2.61 & $\mathrm{H}(21) \cdots \mathrm{H}(45)$ & 2.10 \\
\hline $\mathrm{O}(2) \cdots \mathrm{H}(9)$ & 2.64 & $\mathrm{~F}(7) \cdots \mathrm{C}(43)$ & $3.11(2)$ \\
\hline $\mathrm{F}(2) \cdots \mathrm{C}(7)$ & $3.168(8)$ & $\mathrm{O}(10) \cdots \mathrm{H}(25)$ & 2.71 \\
\hline $\mathrm{C}(1)-\mathrm{F}(1) \cdots \pi(\mathrm{Py})$ & $3.894(7)$ & $\mathrm{O}(1) \cdots \mathrm{H}(44)$ & 2.71 \\
\hline \multirow[t]{5}{*}{$\mathrm{C}(5)-\mathrm{F}(5) \cdots \pi(\mathrm{Py})$} & $3.406(7)$ & $\mathrm{C}(4)-\mathrm{F}(1) \cdot \pi(\mathrm{Py}, \mathrm{N} 3)$ & 3.18(3) \\
\hline & & $\mathrm{C}(13)-\mathrm{F}(9) \cdots \pi(\mathrm{Py}, \mathrm{N} 1)$ & $3.323(11)$ \\
\hline & & $\mathrm{C}(4)-\mathrm{F}(3 \mathrm{~B}) \cdot \pi(\mathrm{Py}, \mathrm{N} 3)$ & $3.487(19)$ \\
\hline & & $\mathrm{C}(13)-\mathrm{F}(7) \cdot \cdots \pi(\mathrm{Py}, \mathrm{N} 3)$ & $3.490(16)$ \\
\hline & & $\mathrm{C}(13)-\mathrm{F}(9 \mathrm{~B}) \cdot \cdots \pi(\mathrm{Py}, \mathrm{N3})$ & $3.497(12)$ \\
\hline
\end{tabular}




\section{Figure Captions}

Figure 1. Structure of the used reagents and expected products.

Figure 2. Evolution of the pressure $(\mathrm{P})$, temperature $(\mathrm{T})$ and stirring rate during the realization of the supercritical crystallization (CSS) experiment for: (a) [Cu(hfacac) $\left.{ }_{2}(\mathrm{PhPy})_{2}\right]$, and (b) $\left[\mathrm{Cu}(\mathrm{hfacac})_{2}(\mathrm{BzPy})_{2}\right]$ and $\left[\mathrm{Cu}(\mathrm{hfacac})_{2}(\mathrm{AcPy})_{2}\right]$. The orange marks indicate the points when the reaction was quenched and a sample was taken. The green areas show the regions with precipitated green particles or crystals.

Figure 3. X-ray diffractograms of the different adducts precipitated using $\mathrm{scCO}_{2}$ and solvent evaporation procedures: (a) [Cu(hfacac) $\left.)_{2}(\mathrm{PhPy})_{2}\right]$, (b) [Cu(hfacac) $\left.)_{2}(\mathrm{BzPy})_{2}\right]$, and (c), (d) $\left[\mathrm{Cu}(\mathrm{hfacac})_{2}(\mathrm{AcPy})_{2}\right]$.

Figure 4. Molecule (a) and two-dimensional layer in the structure of the $\left[\mathrm{Cu}(\mathrm{hfacac})_{2}(\mathrm{PhPy})_{2}\right]$ generated by intermolecular interactions: (b) on the bc plane ( $\mathrm{H}$ atoms except $\mathrm{H} 7$ have been removed for clarity. and (c) cross section, ac plane. In all figures, the disorder found for one of the CF3 groups has been omitted for clarity.

Figure 5. Molecule (a) and two-dimensional layer in the structure of the $\left[\mathrm{Cu}(\mathrm{hfacac})_{2}(\mathrm{BzPy})_{2}\right]$ generated by intermolecular interactions: (b) on the bc plane and (c) cross section. In all figures, the disorder found for one of the $\mathrm{CF}_{3}$ groups has been omitted for clarity. 
Figure 6. (a) Two-dimensional layer in the structure of $\alpha-\left[\mathrm{Cu}(\mathrm{hfacac})_{2}(\mathrm{AcPy})_{2}\right]$ generated by intermolecular interactions: (left) on the (-102) plane (a) and (b) cross section and (c) $\beta$ $\left[\mathrm{Cu}(\mathrm{hfacac})_{2}(\mathrm{AcPy})_{2}\right]$ chains along a direction. In all figures, the disorder found for one of the $\mathrm{CF}_{3}$ groups has been omitted for clarity.

Figure 7. Optical pictures taken from the crystals in the high pressure reactor just after depressurization for: (a) [Cu(hfacac) $\left.)_{2}(\mathrm{PhPy})_{2}\right]$, and (b) [Cu(hfacac $\left.)_{2}(\mathrm{BzPy})_{2}\right]$.

Figure 8. SEM images of crystals of the $\left[\mathrm{Cu}(\mathrm{hfacac})_{2}(\mathrm{PhPy})_{2}\right]$ phase for samples: (a) sp[Cu(hfacac $\left.)_{2}(\mathrm{PhPy})_{2}\right]$, (b) conv[Cu(hfacac $\left.)_{2}(\mathrm{PhPy})_{2}\right]$, and (c,d) src[Cu(hfacac $\left.)_{2}(\mathrm{PhPy})_{2}\right]$.

Figure 9. SEM images of different morphologies observed for the $\operatorname{src}\left[\mathrm{Cu}(\mathrm{hfacac})_{2}(\mathrm{PhPy})_{2}\right]$ sample precipitated following the CSS procedure.

Figure 10. SEM images of crystals of the $\left[\mathrm{Cu}(\mathrm{hfacac})_{2}(\mathrm{BzPh})_{2}\right]$ phase for samples: (a,b,c) $\operatorname{src}\left[\mathrm{Cu}(\mathrm{hfacac})_{2}(\mathrm{BzPy})_{2}\right],(\mathrm{d}) \operatorname{lp}\left[\mathrm{Cu}(\mathrm{hfacac})_{2}(\mathrm{BzPy})_{2}\right]$, and (e) conv[Cu(hfacac $\left.)_{2}(\mathrm{BzPy})_{2}\right]$. 


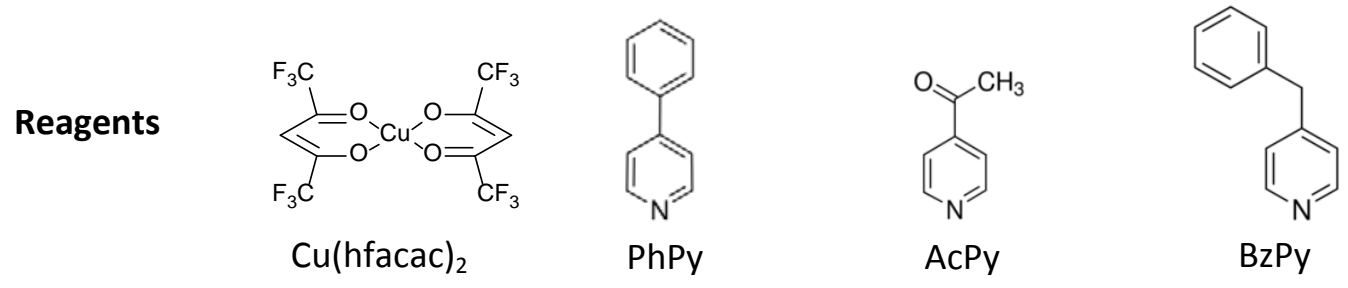

Products

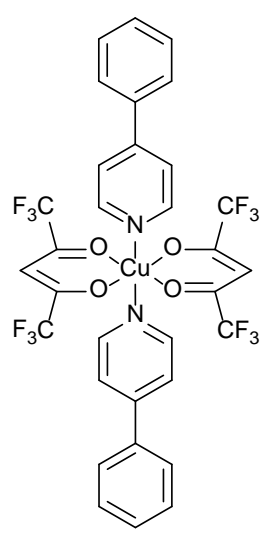

$\left[\mathrm{Cu}(\mathrm{hfacac})_{2}(\mathrm{PhPy})_{2}\right]$

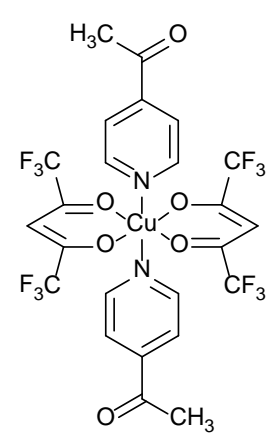

$\left[\mathrm{Cu}(\mathrm{hfacac})_{2}(\mathrm{AcPy})_{2}\right]$

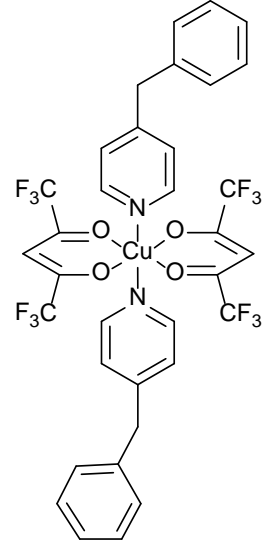

$\left[\mathrm{Cu}(\mathrm{hfacac})_{2}(\mathrm{BzPy})_{2}\right]$

Figure 1. Structure of the used reagents and expected products 

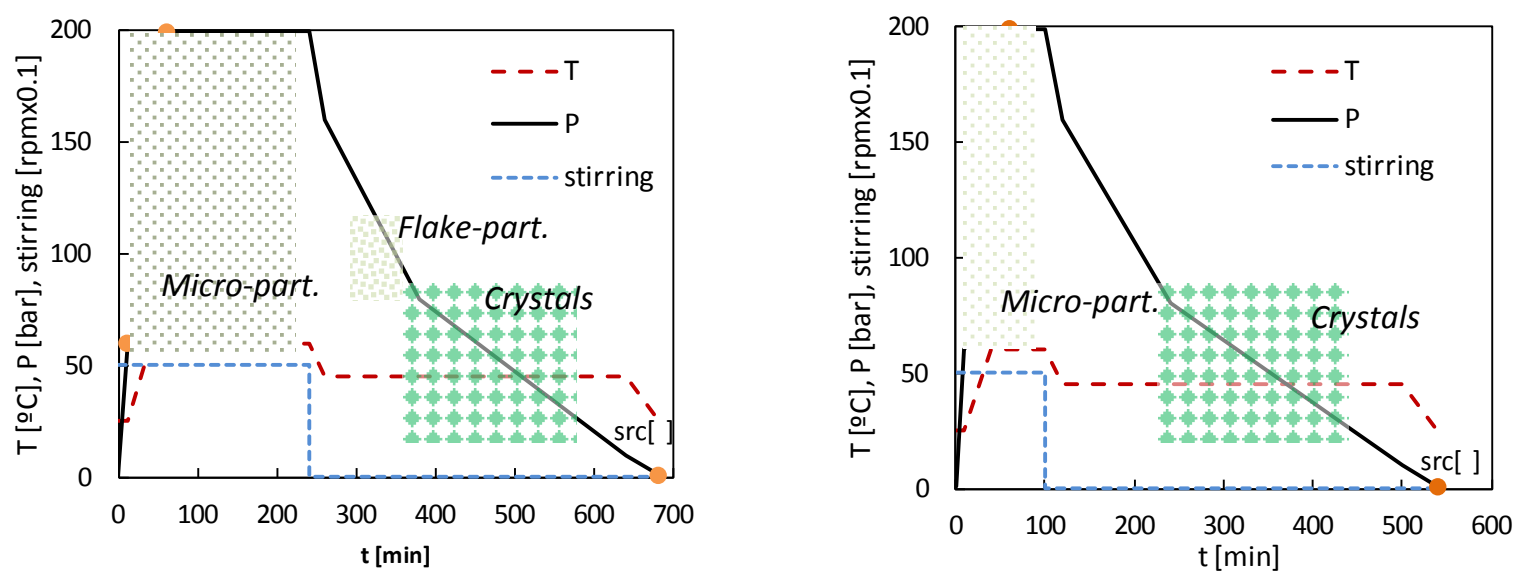

Figure 2. Evolution of the pressure $(\mathrm{P})$, temperature $(\mathrm{T})$ and stirring rate during the realization of the supercritical crystallization (CSS) experiment for: (a) [Cu(hfacac) $\left.)_{2}(\mathrm{PhPy})_{2}\right]$, and (b) $\left[\mathrm{Cu}(\mathrm{hfacac})_{2}(\mathrm{BzPy})_{2}\right]$ and $\left[\mathrm{Cu}(\mathrm{hfacac})_{2}(\mathrm{AcPy})_{2}\right]$. The orange marks indicate the points when the reaction was quenched and a sample was taken. The green areas show the regions with precipitated green particles or crystals. 

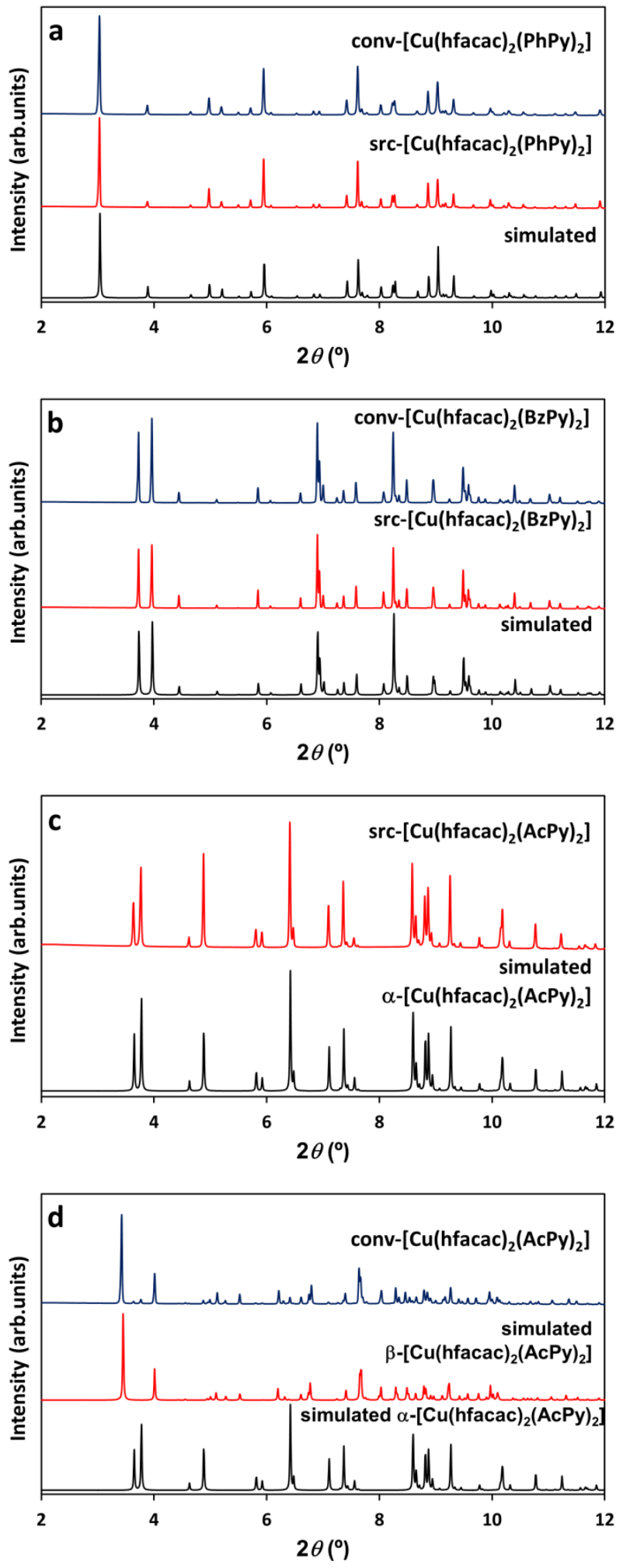

Figure 3. X-ray diffractograms of the different adducts precipitated using $\mathrm{scCO}_{2}$ and solvent evaporation procedures: (a) [Cu(hfacac) $\left.)_{2}(\mathrm{PhPy})_{2}\right]$, (b) $\left[\mathrm{Cu}(\mathrm{hfacac})_{2}(\mathrm{BzPy})_{2}\right]$, and (c), (d) $\left[\mathrm{Cu}(\mathrm{hfacac})_{2}(\mathrm{AcPy})_{2}\right]$. 

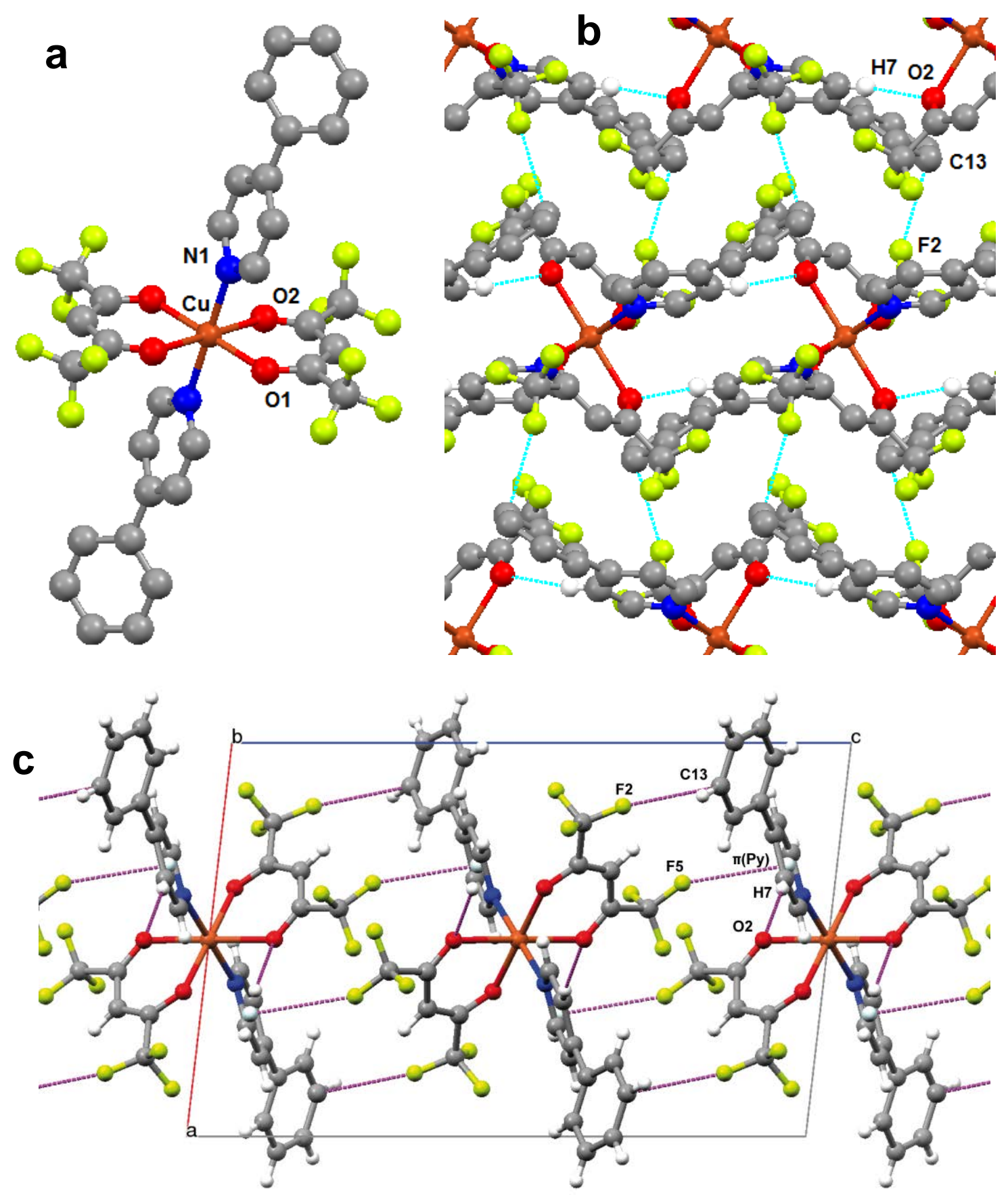

Figure 4. Molecule (a) and two-dimensional layer in the structure of the $\left[\mathrm{Cu}(\mathrm{hfacac})_{2}(\mathrm{PhPy})_{2}\right]$ generated by intermolecular interactions: (b) on the bc plane ( $\mathrm{H}$ atoms except $\mathrm{H} 7$ have been removed for clarity. and (c) cross section, ac plane. In all figures, the disorder found for one of the CF3 groups has been omitted for clarity. 


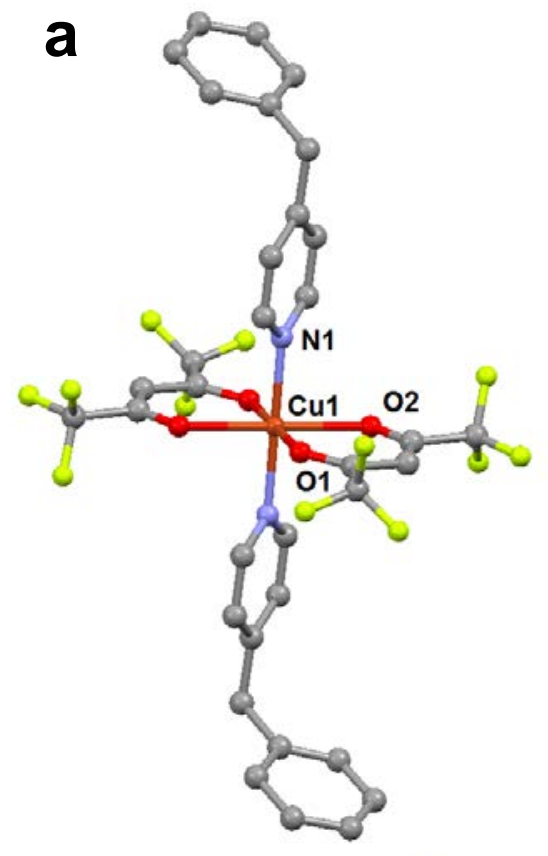

b

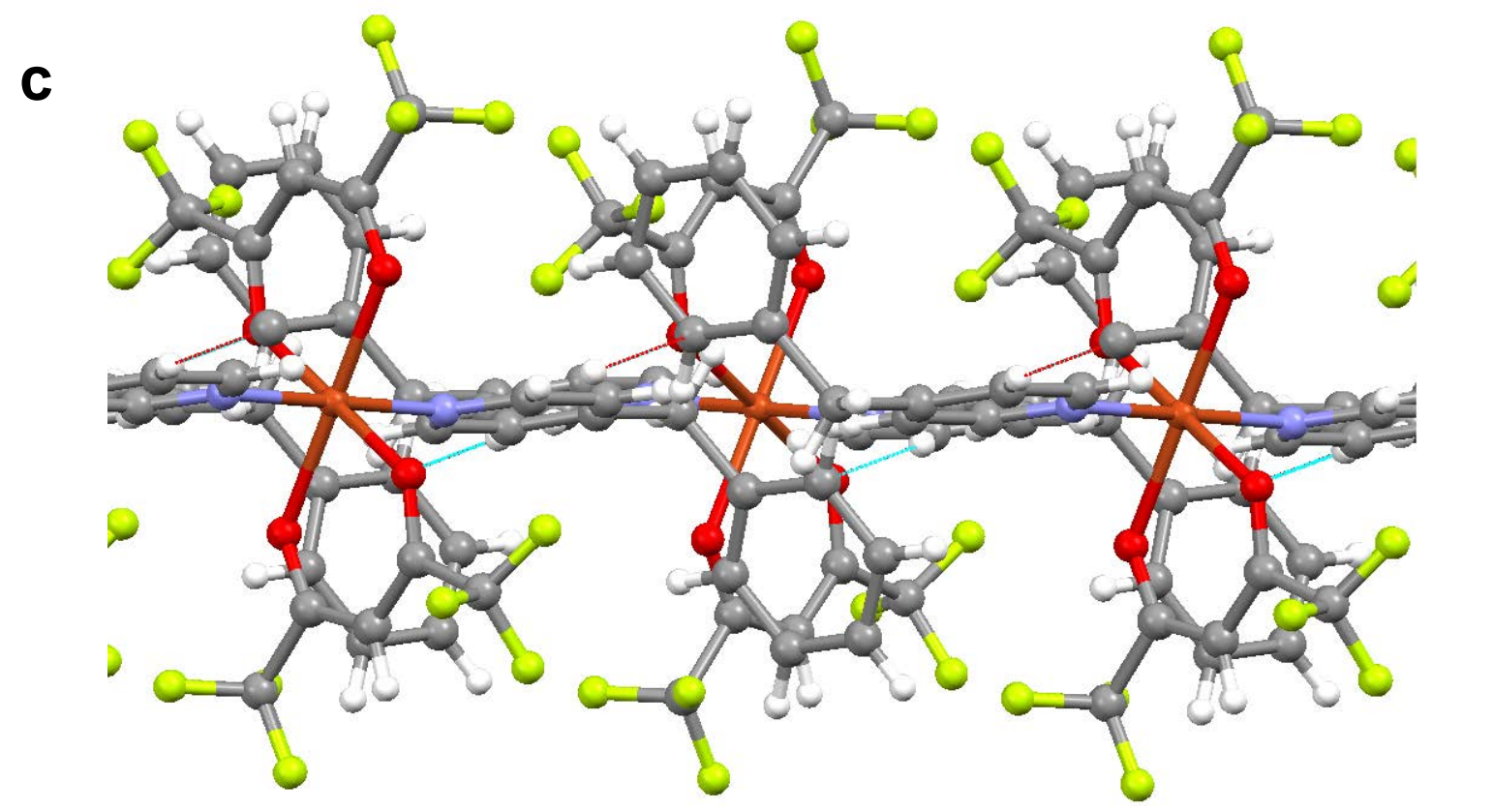

Figure 5. Molecule (a) and two-dimensional layer in the structure of the $\left[\mathrm{Cu}(\mathrm{hfacac})_{2}(\mathrm{BzPy})_{2}\right]$ generated by intermolecular interactions: (b) on the bc plane and (c) cross section. In all figures, the disorder found for one of the $\mathrm{CF}_{3}$ groups has been omitted for clarity. 

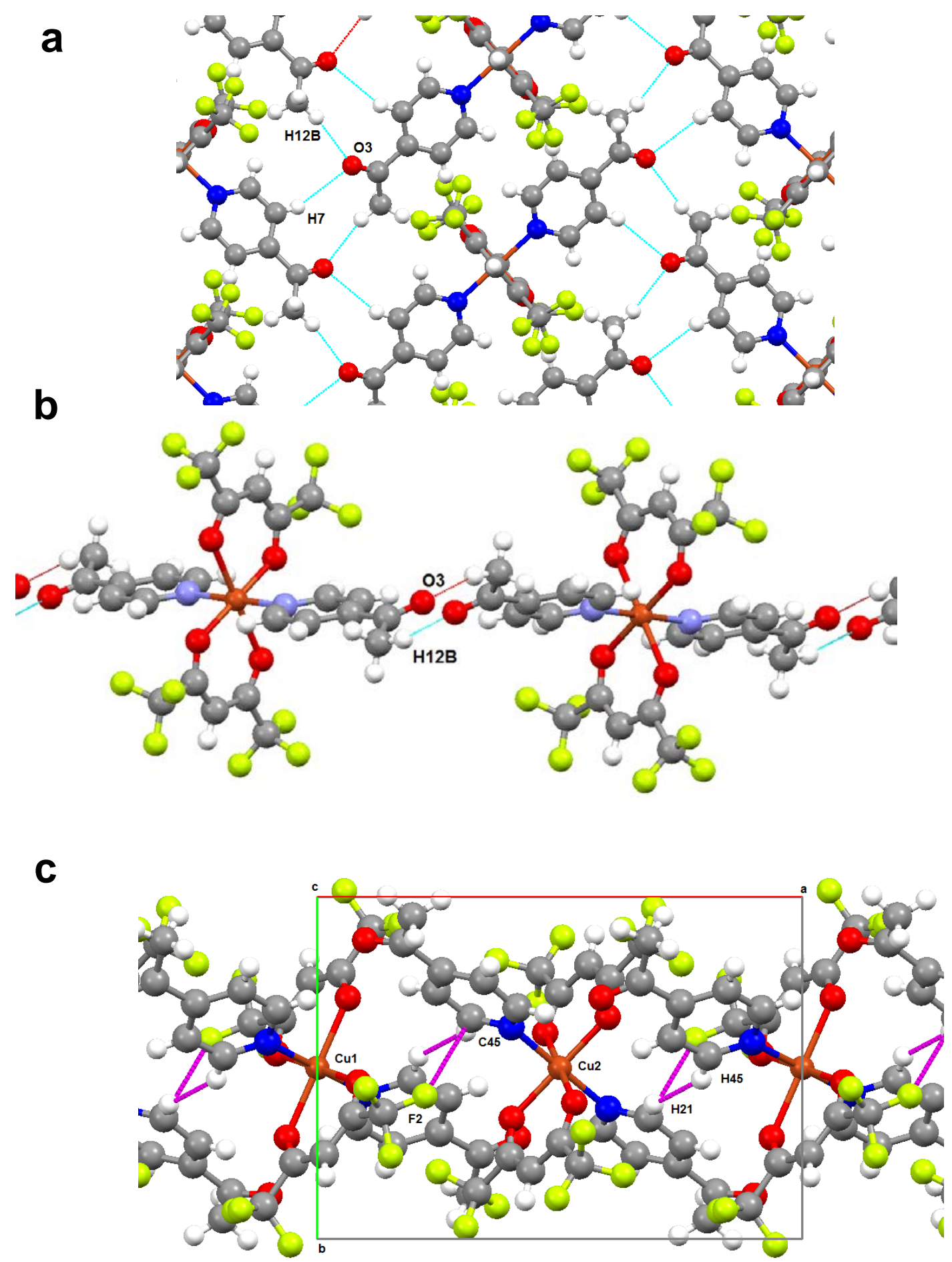

Figure 6. (a) Two-dimensional layer in the structure of $\alpha-\left[\mathrm{Cu}(\mathrm{hfacac})_{2}(\mathrm{AcPy})_{2}\right]$ generated by intermolecular interactions: (left) on the (-102) plane (a) and (b) cross section and (c) $\beta$ $\left[\mathrm{Cu}(\mathrm{hfacac})_{2}(\mathrm{AcPy})_{2}\right]$ chains along a direction. In all figures, the disorder found for one of the $\mathrm{CF}_{3}$ groups has been omitted for clarity. 

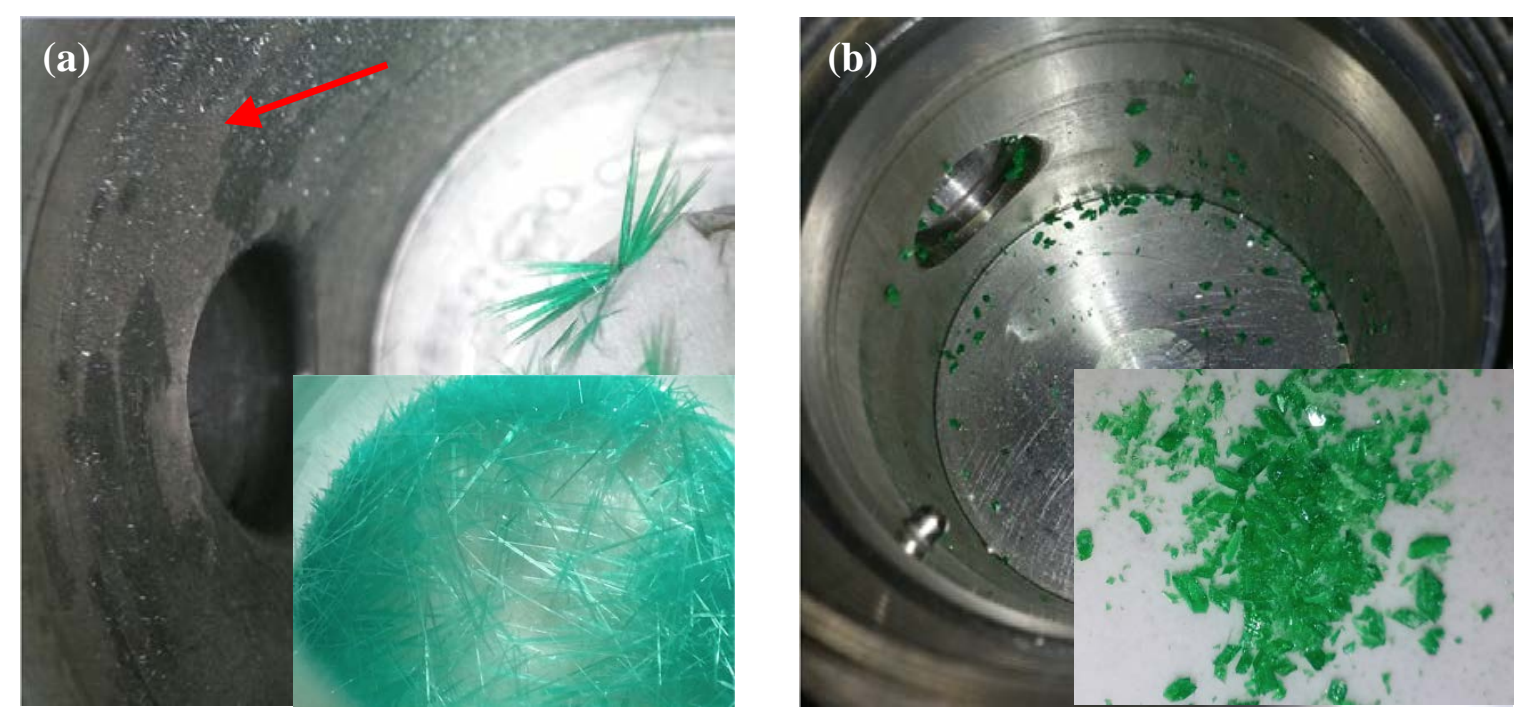

Figure 7. Optical pictures taken from the crystals in the high pressure reactor just after depressurization for: (a) [Cu(hfacac $\left.)_{2}(\mathrm{PhPy})_{2}\right]$, and (b) $\left[\mathrm{Cu}(\mathrm{hfacac})_{2}(\mathrm{BzPy})_{2}\right]$.
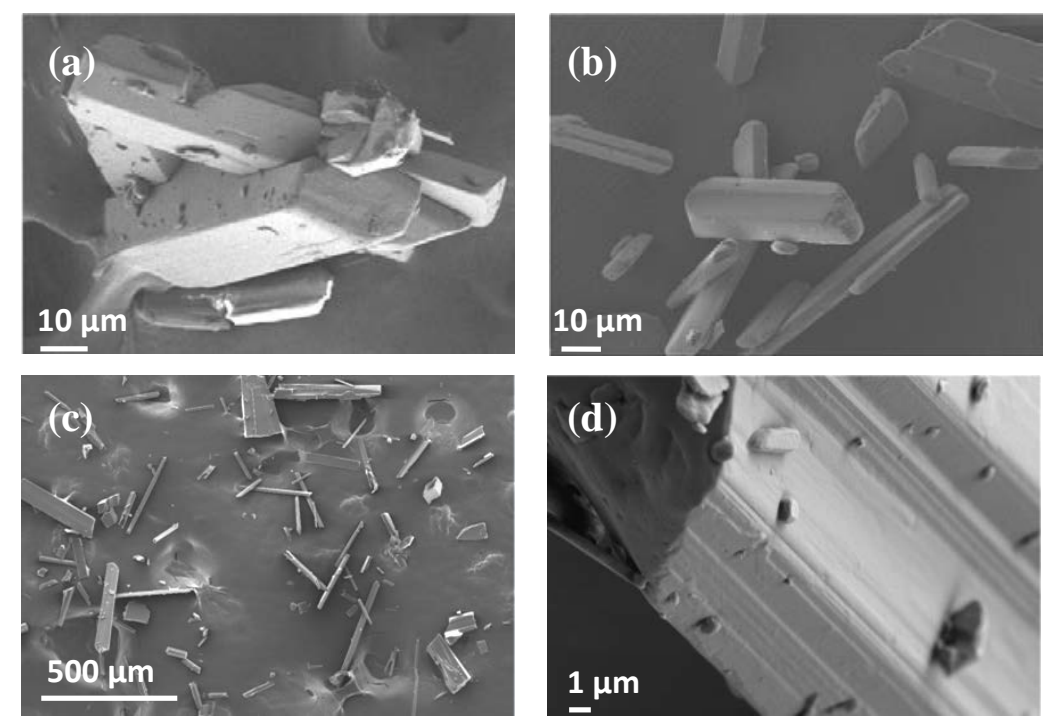

Figure 8. SEM images of crystals of the $\left[\mathrm{Cu}(\mathrm{hfacac})_{2}(\mathrm{PhPy})_{2}\right]$ phase for samples: (a) sp[Cu(hfacac $\left.)_{2}(\mathrm{PhPy})_{2}\right]$, (b) $\operatorname{conv}\left[\mathrm{Cu}(\mathrm{hfacac})_{2}(\mathrm{PhPy})_{2}\right]$, and (c,d) $\operatorname{src}\left[\mathrm{Cu}(\mathrm{hfacac})_{2}(\mathrm{PhPy})_{2}\right]$. 

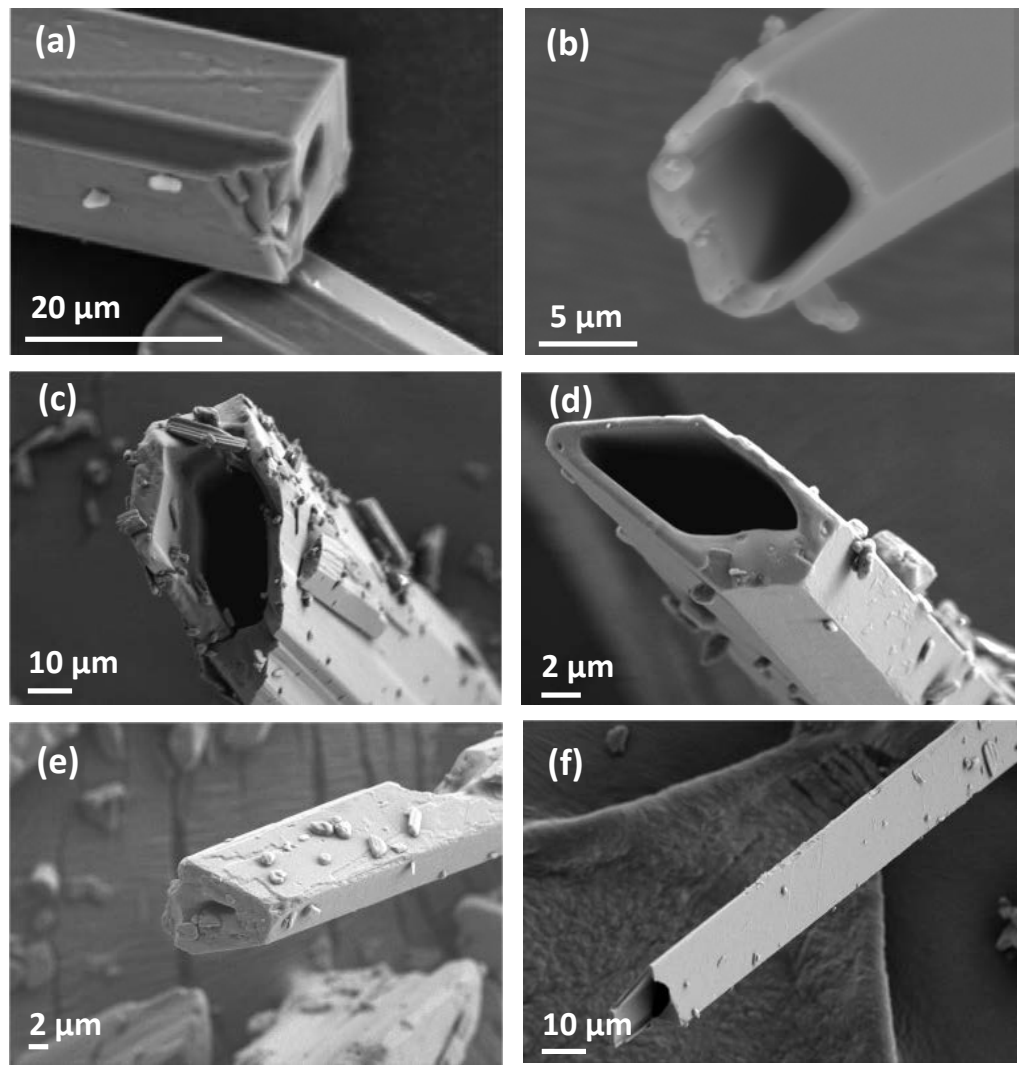

Figure 9. SEM images of different morphologies observed for the $\operatorname{src}\left[\mathrm{Cu}(\mathrm{hfacac})_{2}(\mathrm{PhPy})_{2}\right]$ sample precipitated following the CSS procedure. 

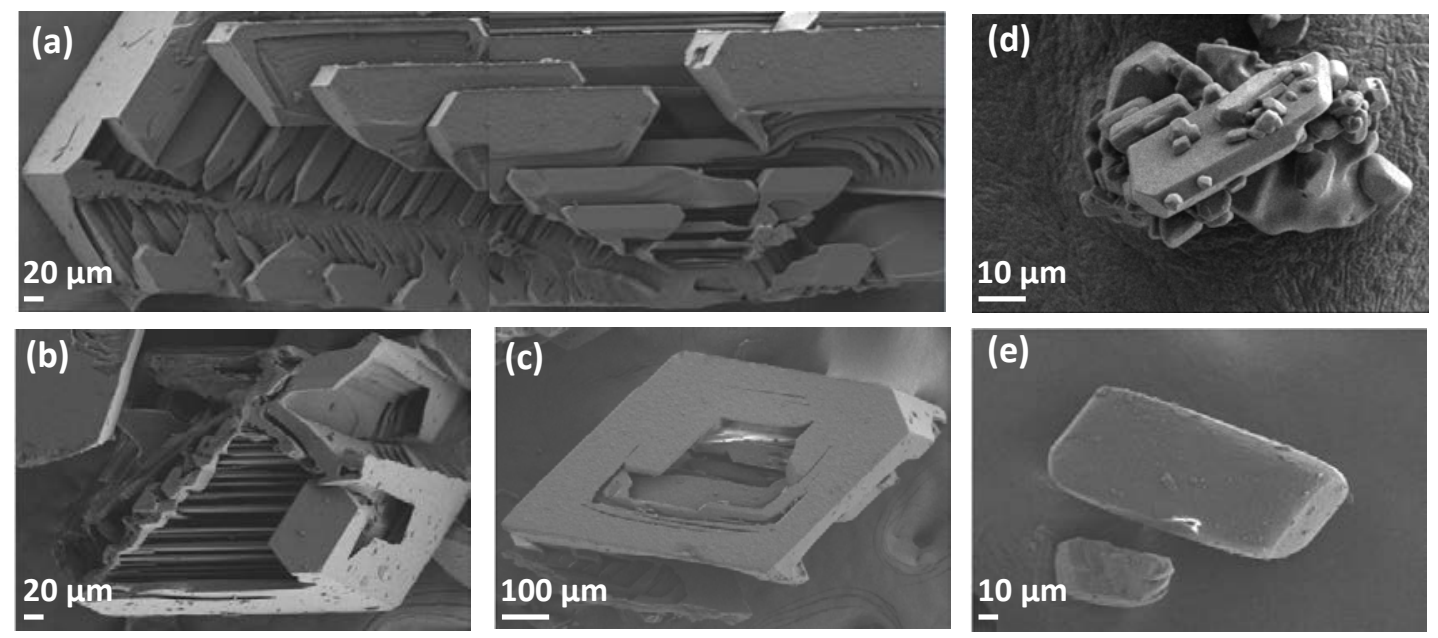

Figure 10. SEM images of crystals of the $\left[\mathrm{Cu}(\mathrm{hfacac})_{2}(\mathrm{BzPh})_{2}\right]$ phase for samples: (a,b,c) $\operatorname{src}\left[\mathrm{Cu}(\mathrm{hfacac})_{2}(\mathrm{BzPy})_{2}\right]$, (d) lp[Cu(hfacac) $\left.)_{2}(\mathrm{BzPy})_{2}\right]$, and (e) $\operatorname{conv}\left[\mathrm{Cu}(\mathrm{hfacac})_{2}(\mathrm{BzPy})_{2}\right]$. 


\section{Supporting Information}

The Supporting Information is available free of charge on the ACS Publications website at DOI: 10.1021/acs.cgd.

Supplementary figures, including additional X-ray diffractograms, ATR-IR spectra and SEM images. 